\title{
La capilla del Cristo de las Descalzas Reales de Madrid: arte y liturgia en el siglo XVI*
}

\author{
$\mathrm{M}^{\mathrm{a}}$ Ángeles Toajas Roger \\ Departamento de Historia del Arte II (Moderno) \\ Universidad Complutense de Madrid \\ matoajas@ucm.es
}

Recibido: 25-02-2015

Aceptado: 12-06-2015

\section{RESUMEN}

Estudio de la capilla del Cristo de las Descalzas Reales de Madrid que analiza la historia de la obra, sus aspectos artísticos y su significado. Las circunstancias de la fundación del monasterio explican la función de la capilla como escenario de las especiales ceremonias litúrgicas del Viernes Santo y del Domingo de Resurrección instauradas en razón de su origen, lo que permite asimismo fijar su ejecución entre las obras de su etapa fundacional, probablemente entre 1560 y 1565 , diseñada por artistas de los talleres reales. Se aporta noticia documental sobre Diego de Urbina y Juan de Cerecedo como pintores al servicio de Juana de Austria en ese momento.

Palabras clave: Descalzas Reales. Madrid. Siglo XVI. Iconografía. Liturgia. Drama paralitúrgico. Viernes Santo. Resurrección. Visitatio Sepulchri. Pascua. Juana de Austria. Francisco de Borja. Gaspar Becerra. Alberto Durero. Diego de Urbina. Juan de Cerecedo. Cristo yacente

\section{The Chapel of Christ at "Las Descalzas Reales" in Madrid: Art and Liturgy in $16^{\text {th }}$ Century}

\begin{abstract}
Study on the Chapel of Christ at the Monastery of Descalzas Reales [Royal Barefoot] in Madrid analyzing its history and its decorative and figurative morphology. The circumstances of origin of this institution explain the liturgical meaning and function of this chapel as a stage for the particular ceremonies of Good Friday and Easter Sunday in this monastery; in the same way, the execution of the work in 1560-1565 $\mathrm{ca}$. by artists of the royal service. New documental evidence is provided about Diego de Urbina and Juan de Cerecedo as painters for Juana de Austria at that moment.
\end{abstract}

\footnotetext{
* Este trabajo forma parte de mi contribución en el Proyecto I+D HAR2010-19406 (Ministerio de Ciencia e Innovación de España). Quiero agradecer desde aquí las facilidades prestadas para este estudio por sor María Rosa, priora de las Descalzas, y por Ana García Sanz, conservadora del monasterio, a quien debo además la medición de la capilla.
} 
Key Words: Descalzas Reales [Royal Barefoot]. Madrid. 16 ${ }^{\text {th }}$ Century. Iconography. Liturgy. Paraliturgical Drama. Good Friday. Resurrection. Visitatio Sepulchri. Easter. Juana de Austria. Francisco de Borja. Gaspar Becerra. Albrecht Dürer. Diego de Urbina. Juan de Cerecedo. Recumbent Christ.

Sumario: 1. Juana de Austria, Francisco de Borja y el ducado de Gandía. 2. La Visitatio sepulchri de Santa Clara de Gandía y las Descalzas de Madrid. 3. Pinturas, imágenes, textos y pintores. 4. Apéndice: relación de textos en las epigrafías de la capilla y sus fuentes.

La capilla del Cristo del Monasterio de las Descalzas Reales de Madrid aparece como uno de sus enclaves más singulares y significativos por cuanto, como aquí veremos, remite precisamente a los orígenes de esta comunidad monástica y, con su revestimiento de pinturas murales, constituye en consecuencia un importante vestigio de arte quinientista en Madrid (fig. 1). A pesar de ello, ha sido muy escasamente atendida salvo por la fama de la imagen a que hace referencia su denominación: un Cristo yacente de bulto en madera policromada de excelente factura y función procesional (fig. 9); esta pieza, por el contrario, es una de las obras artísticas más conocidas del monasterio desde que fuera atribuida a Gaspar Becerra por E. Tormo en $1912^{1}$, una atribución, por cierto, que ha quedado acuñada como autoría cierta en las comunes referencias divulgativas sobre el monasterio o sobre el propio Becerra. Y sin embargo, merece precisamente atención la configuración de la capilla misma, con significativos elementos decorativos, figurativos y epigráficos, de interés aun mayor porque indican que recinto e imagen debieron ser concebidos y realizados uno en función de otro, y todo ello en razón de la propia comunidad monástica concreta según fue instituida. Así pues, nos proponemos aquí un primer estudio de tal conjunto desde una perspectiva integral, analizando los aspectos históricos y artísticos que justifican la obra, y con ellos, la peculiar función litúrgica a que parece responder.

Hay que decir en primer lugar que sobre su ejecución material no hay por el momento noticia documental directa, pero los datos disponibles -que veremos en lo que sigue-, junto a las propias características formales de la obra, permiten creer que debe formar parte de las primeras intervenciones realizadas en el edificio tras ser adquirido por Juana de Austria, Princesa de Portugal, para la instalación del monasterio que fundaba ${ }^{2}$. Sabemos al respecto que estas obras comenzaron en 1559,

1 E. TORMO y MONZÓ, "Gaspar Becerra. Notas varias", Boletín de la Sociedad Española de Excursiones, XX (1912), 67-97; XXI (1913), 117-157 y 242-265; la referencia a este Cristo en: t. XX, p. 67- 71.

2 Por el momento los archivos no han proporcionado material suficiente para detallar en pormenor estas obras que adscribimos al patrocinio de Juana de Austria. Destacando lo sustancial de la documentación directa: E. LLAGUNO/J. A. CEÁN BERMÚDEZ, Noticias de los arquitectos y arquitectura de España, Madrid, 1829, t. II, p. 81 y 98-99: cédula real de 22 de marzo de 1563 ordenando a los regidores de Segovia el envío de doscientas cincuenta vigas de los pinares de Valsaín para el Monasterio "que la serenisima Princesa de Portugal, mi muy cara y muy amada hermana, funda y edifica en esta villa (...) del grueso y largo que entendereis de Antonio Sillero, maestro de las dichas obras"; asimismo, M. A. TOAJAS ROGER, "Juana de Austria y las artes", en Felipe II y las artes, Madrid, Universidad Complutense, 2000, p. 101-115: AGS, Patronato Real, leg. 71, n 113, 137 y 160, actas de las Cortes de Valladolid, 1555: propuesta de 30 de agosto por Juan Vázquez de Molina sobre un servicio a la Princesa Gobernadora por estar construyendo un convento, y acuerdo de 28 de septiembre concediendo 20.000 ducados. La presencia de Gaspar Becerra como autor de los retablos de la iglesia, en J. LÓPEZ 


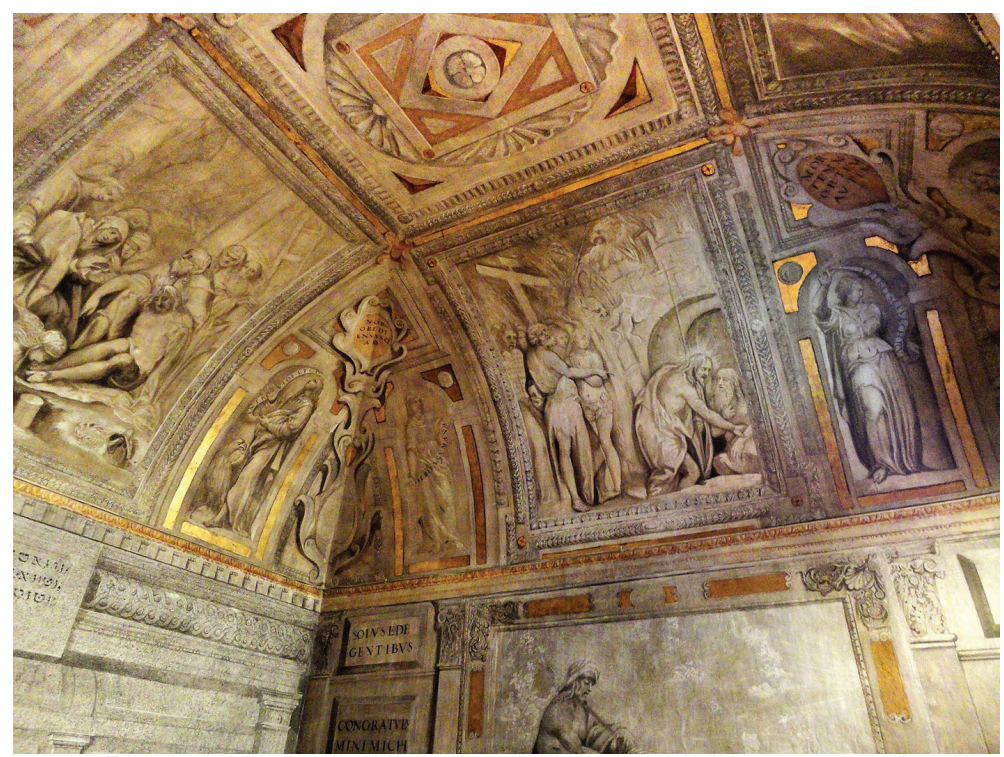

Fig. 1. Monasterio de las Descalzas Reales, Madrid. Capilla del Cristo: vista interior, ángulo noroeste.

cuando se instalan las primeras monjas una vez concluida la compra de la finca, de lo cual informan las crónicas históricas de la fundación en coincidencia con los datos mejor documentados: "finalmente determinose Su Alteza en mandar que [las monjas] viniesen a Madrid, y que alli fuese la fundacion del dicho monesterio, en la misma casa en que nacio que es en la que oy estamos. (...) Mientras se entendio en la venta y compra de la casa, estuvieron las dichas madres con sus religiosas, todas once por aver alli tomado otras dos, en casa del Obispo de Plasençia, (...) En el entretanto todas las religiosas dichas que estavan en la casa del Obispo, el año de 1559, dia de Nuestra Señora de Agosto, en una muy solenne procesion se pasaron a este Monesterio (...). En este mismo año llegó la madre abadesa soror Juana de la Cruz (...) Y despues se anduvo haciendo toda la clausura y oficinas del monesterio, yglesia y coro de manera que el año de 1570 estuvo de todo en todo la obra acabada." $"$.

DE HOYOS, Historia y relacion verdadera de la enfermedad, felicisimo transito y sumptuosas exequias funebres de la Serenissima Reyna de España Doña Isabel de Valoys. Madrid, 1569, f. 39v-48r. Otras referencias directas a encargos artísticos y artífices al servicio de Juana de Austria se deducen, aunque imprecisas, de su testamentaría: actas de las reuniones de sus testamentarios (AP, Descalzas Reales, Caja 1: exp. 1, exp. 2, exp. 15, exp. 18; Caja 4, exp. 11), inventario de bienes y finiquito de los testamentarios, que utilizaremos aquí, vid. infra, nota 77 . La obra mejor documentada es su capilla funeraria, obra que, si bien prevista por ella, fue construida después de su muerte ya por orden de Felipe II, encargada a Jacome Trezzo: C. PÉREZ PASTOR, Memorias de la Real Academia Española, XI (1914), 315-380: AHPM, Prot. 458, fol. 812r-817v, concierto de obra, Madrid, 9 octubre 1574; el documento es utilizado en el estudio de J. ORTEGA VIDAL, "La Capilla sepulcral de Doña Juana en las Descalzas Reales, una joya en la penumbra", Reales Sitios, 138 (1998), 40-54.

3 AGP, Patronatos, leg. 7140, Cronica y historia verdadera de las cosas memorables y particulares del Santo Convento de la Madre de Dios de la Consolación de Madrid y de su fundación y principio, mss. 1594 (fechado en el texto), f. 3r-4v; ya cit. en TOAJAS, op. cit., 2000 (nota 2). 


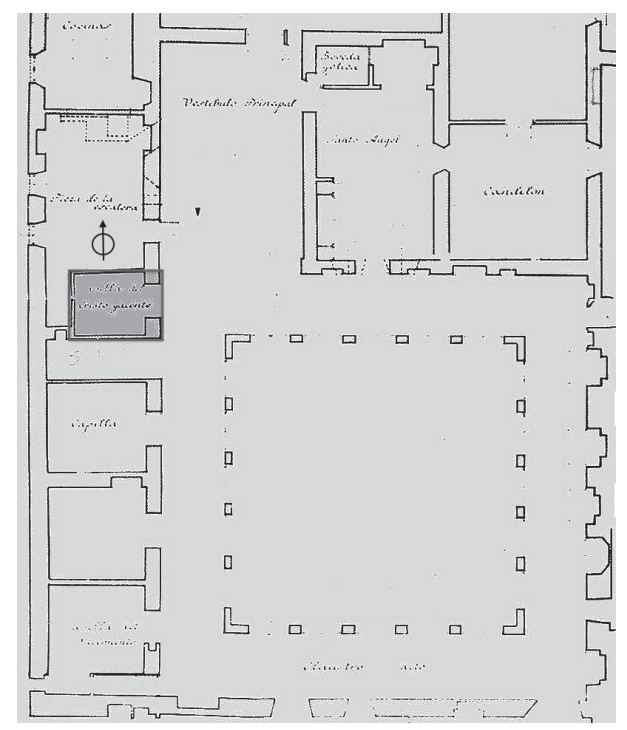

Fig. 2. Monasterio de las Descalzas Reales, Madrid. Planta del claustro alto con ubicación de la Capilla del Cristo (según plano de Diego Méndez, AP, Planos, 3245).

Por otra parte, considerando las circunstancias que rodearon la fundación de la Princesa de Portugal, que enseguida analizaremos, cabe inferir, entre otras cosas, la especial relevancia que esta capilla debió tener para la comunidad inicial y su patrocinadora, por lo que es de suponer que se abordase tempranamente. Así pues, todos los indicios sugieren establecer su datación en la década de 1560, probablemente entre 1563 y 1565, realizándose simultáneamente a la construcción principal llevada a cabo en este momento y la única obra de nueva planta: la regia iglesia que se levanta entre el recinto monástico y el cuarto real con sus jardines para residencia de la propia Princesa que, de acuerdo a sus propósitos, debía ser parte fundamental del conjunto, lo que confiere a esta iglesia un sentido también palatino y en última instancia funerario ${ }^{4}$.

Esta capilla se ubica en la planta alta del claustro principal del monasterio, esto es, el patio que fue núcleo representativo del aristocrático palacio de Alonso Gutiérrez construido entre 1525-35 que Juana adquirió ${ }^{5}$. Está situada en la crujía norte, en su

4 Respecto a las obras de la iglesia, vid. TOAJAS, ibidem, y "Arquitectura en Madrid, 1560: las obras de Juana de Austria y la manera italiana”, en S. DIÉGUEZ PATAO (ed.), Los lugares del arte: identidad y representación. I, Barcelona, Laertes, 2014, p. 43-77; y F. MARÍAS y A. BUSTAMANTE, "De las Descalzas Reales a la Plaza Mayor: dibujos madrileños en Windsor Castle de la colección de Cassiano dal Pozzo", en Cinco siglos de arte en Madrid (XV-XX), Madrid, C.S.I.C., 1991, 73-85.

5 Sobre la historia y morfología de este edificio me remito a M. A. TOAJAS ROGER: "Memoria de un palacio madrileño del siglo XVI: las Descalzas Reales", Reales Sitios, 142 (1999), 18-33; "Capiteles del primer Renacimiento en las Descalzas Reales de Madrid. Estudio del patio del Tesorero", Anales de Historia del Arte-UCM, 13 (2003), 97-130; "El Tesorero Alonso Gutiérrez y su capilla en San Martín. Notas y documentos sobre patronazgo artístico en el Madrid del Quinientos”, Anales de Historia del Arte-UCM, 15 (2005), 87-125; 


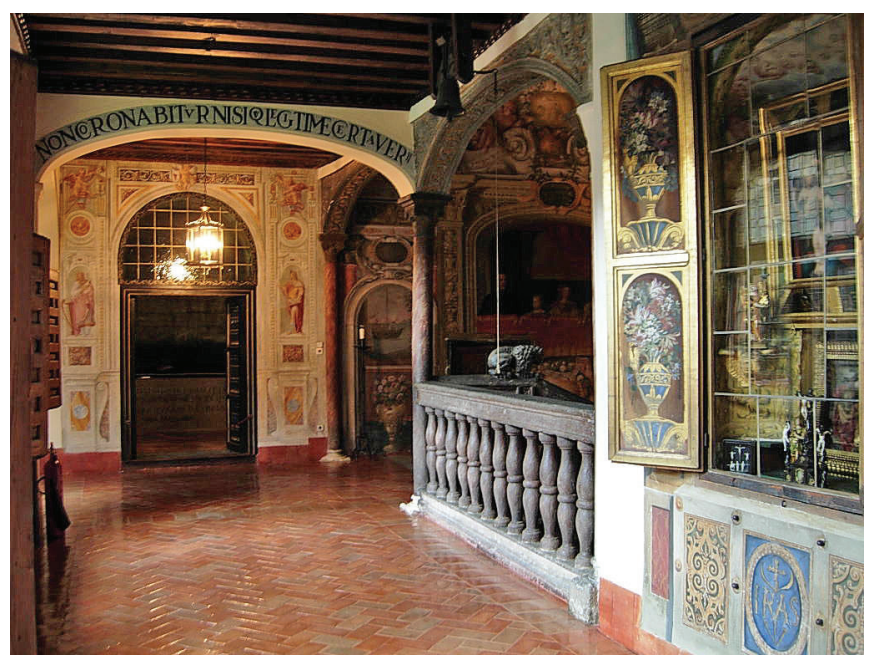

Fig. 3. Monasterio de las Descalzas Reales, Madrid. Capilla del Cristo: vista exterior desde la crujía norte del claustro.

ángulo noroccidental, quedando inmediata al desembarco de la gran escalera monumental del palaciego claustro de modo que su muro testero se orienta al oeste (fig. 2; fig. 3). Se trata de un pequeño recinto de planta cuadrangular levemente oblonga (longitud 3,40 x 3,10 m. anchura) que va cubierto con bóveda esquifada; tal recinto está construido en el interior de una de las salas principales de la casa, de forma que sus muros perimetrales acotan un sector de la superficie del primitivo salón y su alzado queda limitado por la techumbre de madera preexistente, la misma que puede verse todavía hoy en la contigua capilla de San José, como hicimos notar en su momento ${ }^{6}$.

Su morfología general, sus reducidas dimensiones y la baja cota del plano de impostas de la bóveda, que se alza a solo $2,20 \mathrm{~m}$. de altura, dan como resultado un espacio marcadamente cueviforme. En este sentido hay que señalar además que su acceso en origen debió ser de dimensión bastante menor a la que presenta en la actualidad (ancho 1,63 m. x 3,13 m. alto), como queda evidenciado por el modo brutal en que está recortada la pintura situada al interior por encima del vano actual, en una intervención realizada probablemente en la década de 1590 (vid. infra) (fig. 4). El formato original de esta pintura, que puede deducirse de lo que queda de la escena y de la composición decorativa general, permite concluir que la puerta inicialmente no rebasaba en altura la línea de impostas de la bóveda y debió ser seguramente adintelada y más estrecha.

y "Palacios ocultos: las Descalzas Reales de Madrid", en Felix Austria. Lazos familiares, cultura política y mecenazgo artístico entre las cortes de los Habsburgo en el contexto europeo, 1516-1715 (XI Seminario Internacional de Historia), Madrid, Fundación Carlos de Amberes-European Science Foundation RNP Palatium, [2013] en prensa.

6 M. A. TOAJAS ROGER, "Arquitectura del Monasterio de las Descalzas Reales de Madrid: la capilla de San José”, Anales de Historia del Arte-UCM, 8 (1998), 127-147. 


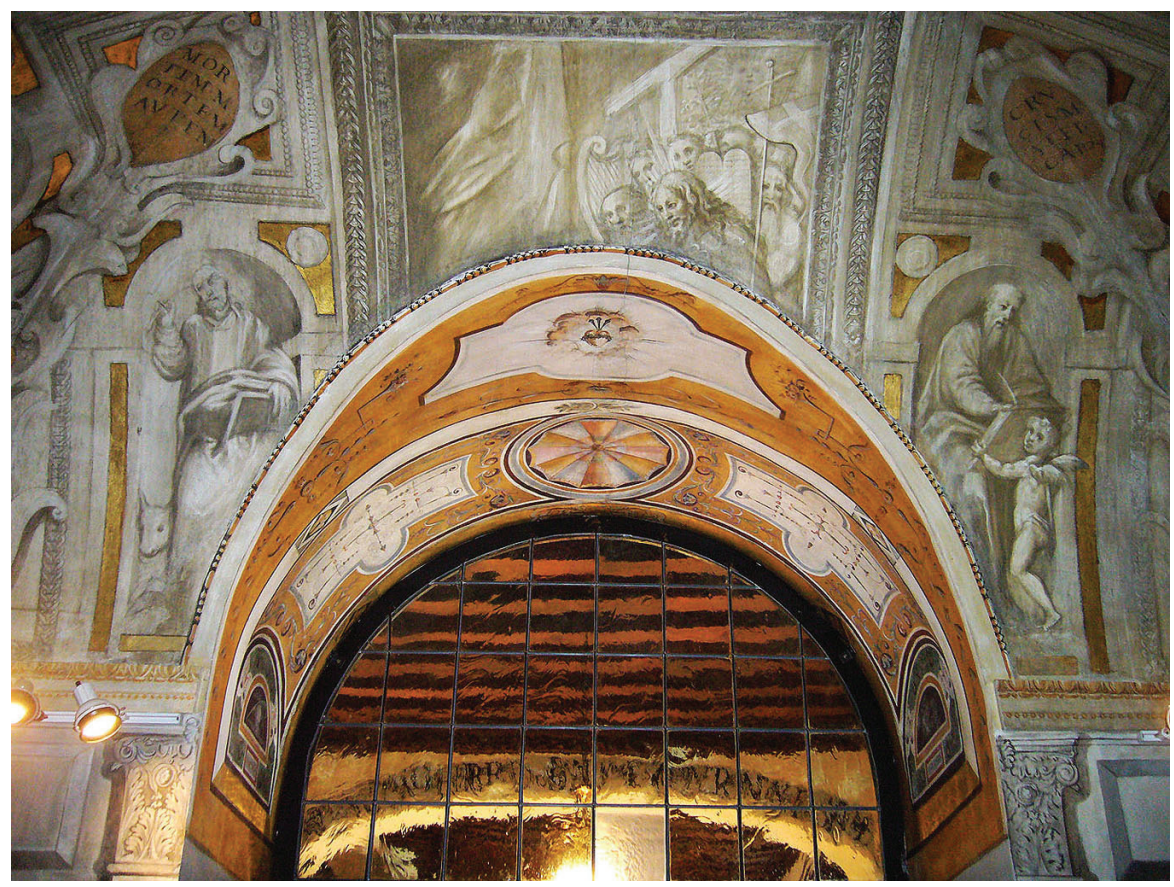

Fig. 4. Monasterio de las Descalzas Reales, Madrid. Capilla del Cristo: interior del arco de acceso y paño oriental de la bóveda con fragmento del tema Aparición de Cristo a su madre y figuras de San Mateo y San Lucas.

En conjunto, la configuración de la capilla, con las pinturas y el notable repertorio de textos epigráficos que contiene, define un espacio sacro, recóndito y fúnebre, concebido como sede de la imagen del Cristo yacente, que sin duda se debió realizar simultáneamente; un ámbito que puede entenderse como un trasunto del sepulcro mismo, aunque representado también como escenario de la Resurrección tal como indican las pinturas que le rodean. La figura del cuerpo muerto de Cristo forma parte de esta representación que, en definitiva, como se verá, está ideada y compuesta en función de las ceremonias litúrgicas a las que sirven tanto la imagen como el propio espacio de la capilla, y tanto desde el punto de vista simbólico como físico.

El diseño, por su parte, responde al gusto por una suntuosidad severa, según una idea del decorum regio que parece haber presidido siempre las decisiones de la Princesa de Portugal en materia artística ${ }^{7}$, o quizá también de sus mentores, principalmente Francisco de Borja y, en este caso, además de las monjas de Santa Clara de Gandía, cuyos papeles resultan esenciales para la comprensión de estas obras, y es por donde conviene comenzar su estudio.

7 TOAJAS, op. cit., 2000 (nota 2) y TOAJAs, op. cit., 2014 (nota 4). 


\title{
1. Juana de Austria, Francisco de Borja y el ducado de Gandía
}

Como apuntábamos, la contrucción de la capilla del Cristo debe remontarse al momento inicial de la historia del Monasterio y a las circunstancias concretas que ahí concurren, de modo que parece oportuno analizar con algún pormenor los hechos que están en el origen de esta fundación monástica que toma cuerpo entre 1554 y 1559.

La iniciativa de Juana de Austria como promotora de tal fundación es ampliamente glosada y ensalzada por las crónicas históricas sobre el Monasterio, entre las que destacan la citada de 1594, como más temprana, y la subsiguiente publicación de fray Juan Carrillo, Relacion historica de la Real Fundación del Monasterio de las Descalzas de Santa Clara de la Villa de Madrid, con las vidas de su Fundadora y de la Emperatriz María, su hermana (Madrid, 1616), la fuente más difundida, que depende en parte de la anterior. Sus relatos sobre el origen de la institución tienden a destacar por encima de todo el papel de la Princesa fundadora con un sentido casi hagiográfico propio de ese tipo de textos, lo que se justifica, por otra parte, por la importancia tanto representativa como material de tal patronazgo; sin embargo, su visión obvia la incidencia efectiva de los factores y personas que en realidad hacen posible la concreción de la empresa (como suele suceder, por cierto, en lo relativo a la promoción de obras artísticas), y en este caso, la intervención de Francisco de Borja, IV duque de Gandía y jesuita profeso desde 1548. Su presencia es mencionada siempre como vehículo de la inspiración divina en la Princesa, de acuerdo a la fama de santidad que su renuncia a títulos y estados le granjeó, pero en la fundación de las Descalzas de Madrid es mucho más concreta y determinante y, para lo que aquí nos ocupa, es el motivo de haberse instituido al amparo de las clarisas de Gandía.

Ciertamente es conocida su proximidad a Juana de Austria ${ }^{8}$, pero es precisamente en la formación del monasterio madrileño donde queda más patente, poniendo de manifiesto cómo las decisiones de la Princesa al respecto dependieron de los criterios de su mentor, que fue actor esencial en el proceso como se desprende de hecho de la citada crónica:

\begin{abstract}
“(...) traxo Su Alteza para este monasterio que queria fundar por piedra primera y fundamental a la madre Soror Francisca de Jesús, tia del mismo padre Francisco y hermana de su padre, con la madre Soror Maria de Jesus, su prima hermana hija del marques de Denia, y otras quatro religiosas, (...)se les murio la madre abadesa soror Maria de Jesus (...) Viendose pues quedar sin aver conseguido el fin de su fundacion, (...) pidieron que de la misma casa de Gandía de donde ellas todas avian venido, mandase venir a soror Juana de la Cruz, sobrina de la dha soror Francisca de Jesus, hija de los Duques de Gandía don Juan de Borja y doña Francisca de Castro, (...) el año de $1559,(\ldots)$ llegó la madre abadesa soror Juana de la Cruz (...)”.
\end{abstract}

8 Cf. TOAJAS, op. cit., 2000 (nota 2). Para el tema es de referencia M. BATAILLON, "Jeanne d'Autriche, Princesse de Portugal", en Études sur le Portugal au temps de l'Humanisme, Universidad de Coimbra, 1952, p. 257-283, que analiza aspectos concretos de su relación y también en la coyuntura de la espiritualidad y la iglesia españolas del momento; para el contexto general, también ID., Erasmo y España, México, Fondo de Cultura Económica, 1966 ( $2^{\mathrm{a}}$ ed. corregida y aumentada). Asimismo, A. ASTRAIN, S. I., Historia de la Compañia de Jesús en su asistencia de España, Madrid, 1905, t. I y t. II, cap. V y cap. VII. 
La presencia de Borja en la vida de esta infanta, hija menor de Carlos V, puede seguirse a lo largo de la biografía de la Princesa desde su nacimiento 9 . Por esta fecha, en 1535, ostentaba el título de Marqués de Lombay y ejercía como Caballerizo Mayor de la emperatriz Isabel, honores ambos recibidos con motivo de su matrimonio en 1529 con Leonor de Castro, una de las damas portuguesas de la Emperatriz, a su vez designada su Camarera Mayor ${ }^{10}$. Había llegado a la corte un año antes, con dieciocho años, procedente de Zaragoza, donde se educó desde los once con su abuelo el arzobispo Alonso de Aragón tras haber salido de Gandía durante los episodios de las germanías en 1521. Muerta la Emperatriz en 1539, el marqués pasaría a ocupar el cargo de Virrey de Cataluña, donde sirvió a la corona hasta 1543 en que muere su padre y hereda el ducado de Gandía, trasladándose poco después a sus estados ${ }^{11}$. Su carrera palatina continúa, no obstante, pues en esa fecha, ante el inminente matrimonio del príncipe Felipe con María Manuela de Portugal, el Emperador determina designar a los nuevos duques como Mayordomo Mayor y Camarera Mayor de la nueva

9 Para la biografía de Juana de Austria, los principales aportes de fuentes primarias en: A. DANVILA y BURGUERO, Don Cristóbal de Moura, primer marqués de Castel Rodrigo, Madrid, 1900; A. RODRÍGUEZ VILLA, La reina Juana la loca. Estudio histórico, Madrid, 1892; ID., "El Emperador Carlos V y su corte", BRAH, XLII (1903 -1), 468-481; XLIII (1903 -2), 5-240 y 393-511; XLIV (1904 -1), 5-36, 142-178, 197-245, 285-332, 365-413 y 465-506; XLV (1904 -2), 16-143, 315-352, 369-405 y 465-495; XLVI (1905 -1), 5-44; y L. FERNÁNDEZ DE RETANA, Juana de Austria, Madrid, El Perpetuo Socorro, 1955, que trae el corpus documental de conjunto extraído sobre todo del Archivo General de Simancas, por lo que, pese a su tono hagiográfico escasamente científico, sigue siendo obra de referencia. Asimismo, sobre su nacimiento y primeros años: J. MARCH, Niñez y juventud de Felipe II, Madrid, 1941 (el interesante epistolario de Estefanía de Requesens, editado posteriormente por M. GUISADO, Estefania de Requesens. Cartes intimes d'una dama catalana del s. XVI. Epistolari a la seva mare la Comtessa de Palamós, Barcelona, La Sal, 1988). Respecto a su papel político, J. MARTÍNEZ MILLÁN, "Familia real y grupos políticos: la princesa doña Juana de Austria" en J. MARTÍNEZ MILLÁN (dir.), La corte de Felipe II, Madrid, Alianza Ed., 1994, pp. 73-105. Una biografía recopilatoria en A. VILLACORTA, La jesuita. Juana de Austria, Barcelona, Ariel, 2005.

10 Respecto a Francisco de Borja, las fuentes históricas principales son: P. de RIVADENEYRA, Vida del P. Francisco de Borja, que fue Duque de Gandía y III General de la Compañia de Jesus, Madrid, P. Madrigal, 1592; J. E. NIEREMBERG, S. I., Vida del Santo Padre el B. Francisco de Borja, tercero General de la Compañia de Jesus y antes IV duque de Gandia, Madrid, M de Quiñones, 1644; Á. de CIENFUEGOS, S. I., La heróyca vida, virtudes y milagros del Grande San Francisco de Borja, antes Duque quarto de Gandia y después Tercero General de la Compañía de Jesús, Madrid, Viuda de García Infanzón, 1702; y el manuscrito de D. VÁZQUEZ, S. I., Historia de la vida del P. Francisco de Borja, tercero general de la Compañía de Jesús (1580 ca.), transcripción, estudio introductorio y notas de S. LA PARRA LOPEZ, Gandía, CEIC Alfons el Vell, 2011; y asimismo, los repertorios documentales de la Compañía de Jesús. Entre los estudios históricos, además de la obra citada de A. ASTRAIN (supra nota 8), cabe destacar: P. SUAU, S. I., Historia de S. Francisco de Borja. Tercer General de la Compañía de Jesús (1510-1572), Zaragoza, Hechos y Dichos, 1963 (1 $1^{\mathrm{a}}$ ed. francesa: 1905, aumentada 1910); C. DE DALMASES, S. I., El padre Francisco de Borja, Madrid, Biblioteca de Autores Cristianos, 1983; M. BATLLORI, La familia Borja, Valencia, E. Climent ed., 1994; S. LA PARRA LÓPEZ y M. TOLDRÀ (eds.), Francesc de Borja (1510-1572), home del Renaixement, sant del Barroc. Actes Simposi Internacional, Gandía, CEIC Alfons el Vell-Institut Internacional d'Estudis Borgians, 2010 [ed. digit.; también en Revista Borja, 4 (2012-2013)], y asimismo, otras aportaciones de S. LA PARRA LÓPEZ que se citarán.

$11 C f$. S. LA PARRA LÓPEZ: "San Francesc de Borja, duc abans de sant", en L'Europa renaixentista. Simposi sobre els Borja, Gandía, CEIC Alfons el Vell, Ed. Tres i Quatre, 1998, pp. 271-306; "El ducado de Gandía y la memoria familiar de San Francisco de Borja", (Actes II Simposi Internacional sobre els Borja) Revista Borja, 2 (2008-2009), pp. 81-103, y "Francisco de Borja y Gandía: la formación del cortesano", en Francesc de Borja (1510-1572), home del Renaixement, sant del Barroc. Actes Simposi Internacional, Gandía, CEIC Alfons el Vell-Institut Internacional d'Estudis Borgians, 2010, pp. 83-105. 
princesa, servicios de relieve que sin embargo no llegarían a hacerse efectivos por la oposición inicial de los reyes de Portugal y la prematura muerte de esta princesa en julio de $1545^{12}$.

El decurso cortesano de Francisco de Borja dependió, como es sabido, de su entorno familiar. Había nacido en 1510, en el seno de una familia de influencia ascendente en el reino de Aragón desde cincuenta años atrás, cuando por primera vez uno de sus miembros había alcanzado el trono pontificio: Alonso de Borja, papa Calixto III, en $1455^{13}$. A fin del siglo un segundo Borja llegará también a papa: Rodrigo, hijo de una hermana del anterior, que había sido beneficiado con el capelo cardenalicio en 1456 por su tío Calixto III; será pontífice como Alejandro VI de 1492 a 1503, tras una activa y larga vida política en la curia romana, manteniendo también varias relaciones de concubinato de las que nacen seis hijos. Fue para su primogénito, Pedro Luis de Borja, para quien el cardenal adquirió del Rey Católico el ducado de Gandía en 1485 con motivo de su matrimonio ${ }^{14}$, enseguida heredado por su hermano Juan de Borja, que en 1488 será el II duque de Gandía por la temprana muerte del primero. El primogénito y único hijo varón de este será Juan de Borja y Enríquez de Luna, III duque y padre de Francisco.

Al mismo tiempo, la familia emparenta con la corona de Aragón en esas dos generaciones sucesivas. El segundo duque, Juan, casó en 1493 con María Enríquez de Luna, la viuda de su hermano muerto sin descendencia; María Enríquez era prima de Fernando el Católico por cuanto fue hija de Enrique Enríquez, hermano de Juana Enríquez, la madre del rey. En la siguiente generación se mantiene tal vínculo a través del matrimonio del III duque de Gandía, Juan de Borja y Enríquez de Luna, con Juana de Aragón, que era nieta del rey Fernando como hija natural de Alonso de Aragón, arzobispo de Zaragoza y Virrey de Aragón, hijo natural a su vez del monarca.

Hay que destacar aquí -aunque volveremos sobre ello- la poderosa presencia en la familia de María Enríquez de Luna (1470 ca.-1537), segunda duquesa y abuela de Francisco de Borja, igualmente decisiva en cuanto al patronazgo y estrechísima vinculación del ducado al convento de clarisas de Gandía, donde morirá como monja ${ }^{15}$. Casada sucesivamente, como se ha dicho, con los dos primeros duques de Gandía de la casa de Borja, ambos matrimonios fueron breves; muerto el primer duque sin descendencia, casa con su cuñado Juan en 1493, cuando su suegro acaba de alcanzar el pontificado, pero este segundo duque moriría solo cuatro años después, asesinado en Roma en junio de 1497. Ejerció la regencia del ducado desde entonces defendiendo

12 LA PARRA, op. cit., 2010 (nota 11), p. 84.

13 Para lo que sigue me remito con carácter general a BATLLORI, 1994, op. cit. (nota 10).

14 Este título fue instituido en 1399 por Martín el Humano para su tío Alfonso de Aragón y Foix; su hijo Alfonso de Aragón el joven, segundo duque, muere sin descendencia legítima en 1422 y el ducado vuelve a la corona. Precisamente con los bienes de esa herencia su hermana Violante de Aragón funda en 1430 en Gandía un monasterio de franciscanas sujeto a la reforma observante que tiene una vida efímera, pues a su muerte, hacia 1442, es abandonado por pleitos interpuestos por sus sobrinas sobre esa herencia, y la comunidad de clarisas observantes se traslada a Valencia; para esto L. AMORÓS, O.F.M., "El Monasterio de Santa Clara de Gandía y la familia ducal de los Borjas", Archivo ibero americano, 80 (1960), pp. 441-486; 82-83 (1961), pp. 227-282, y 84 (1961), pp. 399-458, estos episodios en p. 453-457.

15 AMORÓS, ibidem, (1961), pp. 227-234. 
la herencia de los dos hijos nacidos de este matrimonio: Juan (1495-1543), III duque de Gandía, e Isabel (1498-1557) ${ }^{16}$. Fue a la mayoría de edad de su primogénito cuando se retira al monasterio gandiense, donde poco antes, en 1510, había ingresado también su hija Isabel de Borja como sor Francisca de Jesús; esta llegaría a ser priora de Santa Clara en 1533 y es quien, con la mediación de su sobrino Francisco, se convertirá al final de su vida en artífice principal de la nueva comunidad patrocinada por la Princesa de Portugal, de la que será primera abadesa, aunque muere en el inicio mismo del proceso. Estas dos mujeres construyen el vínculo fundamental de la familia ducal con las clarisas de Gandía, que se extenderá a la fundación de las Descalzas de Madrid.

Volviendo a Borja y la corte, su presencia se transforma con el sustancial giro que, como se sabe, tomará en 1546, solo tres años después de heredar el ducado, cuando, al enviudar, se incorpora a la Compañía de Jesús y profesará como jesuita en 1548, renunciando a su título ducal en favor de su primogénito, Carlos de Borja ${ }^{17}$. Sin embargo, eso no impidió mantener su proximidad a la familia imperial, lo que constituía un importante valor para los intereses de la nueva orden, tanto para lograr adhesiones y patronatos de relieve, como por el significado del hecho mismo para la propaganda de la organización. En ese sentido, del impacto del caso da idea el que, según el cauteloso criterio del propio Ignacio de Loyola, en un primer momento se mantuviera en secreto, advirtiendo a Borja tras sus votos simples que "el mundo no tiene orejas para oir tal estampido" 18; y lo mismo se desprende de las palabras que le dirige el Emperador ya en 1551 en carta desde Augsburgo (12 de febrero), "entiendo que de lo que emprendéis hacer tendréis más envidiosos que imitadores, porque teneros envidia costará poco y el seguiros mucho» ${ }^{19}$. En definitiva, su importante papel para los jesuitas en las cortes de Castilla, Aragón y Portugal se concreta en su designación como Comisario de la Compañía en España y Portugal a partir de 1554.

De hecho, su proximidad con la familia imperial se afianza entre 1548 y 1558 . Es significativo cómo Carlos V, desde Yuste, recurre a Borja en 1558 como embajador discreto ante los problemas de la regencia en Portugal por la minoridad del rey Sebastián y eventualmente por su sucesión ${ }^{20}$. Sin embargo, su situación cambiará poco después de la muerte del Emperador, cuando se desencadena el momento de mayor

16 Alejandro VI, a la muerte de su segundo hijo, pretendió traspasar el ducado al tercero, César, lo que fue impedido por doña María con el apoyo de su primo Fernando el Católico, $c f$. BATLLORI, op. cit. (nota 9), p. 189, nota 46: testimonio del embajador de Mantua en Roma, el 18 de agosto de 1498, según el cual el papa se lamentaba porque los hijos del duque de Gandía "sono più prossimi parenti al re di Spagna che a lui, e nati da sorella del patre del re predetto". Vid. también LA PARRA, 2010, op. cit. (nota 11), p. 104.

17 M. RUIZ JURADO, S. I., «La entrada del Duque de Gandía en la Compañía de Jesús», Manresa, 44 (1972), pp. 121-144. Leonor de Castro murió el 27 de marzo de 1546; en mayo siguiente realizó Borja los ejercicios ignacianos con el P. Andrés de Oviedo (primer rector del colegio y universidad de Gandía) y el 2 de junio hizo los votos simples; el 1 de febrero de 1548 tuvo lugar en secreto su profesión solemne, en la que inicialmente no se incluía el cuarto voto de la Compañía.

18 ASTRAIN, op. cit., (nota 8), t. I, p 285 y ss.: carta de fecha incierta, probablemente de principios de octubre de 1546. Vid. también L. FRİAS, S. I., «La profesión del Duque de Gandía. Ampliación y rectificaciones de los historiadores según las fuentes», AHSI, V (1936), pp. 106-114.

19 Citado por LA PARRA, op. cit., 2010 (nota 11), p. 94: MHSI, Borgia, I, p. 309.

20 ASTRAIN, op. cit., (nota 8), t. II, cap. VII. 
virulencia inquisitorial contra todo vestigio de espiritualismo y Borja se ve afectado también por las invectivas del dominico Melchor Cano y el Inquisidor General Valdés. La causa visible fue una edición de Obras del Christiano del Duque de Gandía (Alcalá, 1556; se había publicado una primera parte en Medina, 1552) considerada dudosa, aunque los ataques responden también a la oposición de un importante sector de los dominicos contra los jesuitas. Finalmente, Francisco de Borja sale a Portugal para desde allí, atravesando Castilla subrepticiamente, alcanzar Roma en septiembre de $1561^{21}$. En 1564 será elegido tercer General de la Compañía, cargo que ejercería hasta su muerte en 1572 .

En cuanto a su influencia en la vida de la infanta Juana, es también más significativa tras la adhesión del duque a los iñiguistas. Cuando Borja profesa en 1548, la futura Princesa tiene trece años y está a la espera de alcanzar la edad para su boda con el heredero de Portugal, matrimonio concertado en 1542, -con el del príncipe Felipe con María Manuela, en un doble compromiso entre hermanos-; la boda se celebraría por poderes a comienzos de 1552, aunque la infanta no viajaría a Lisboa hasta fines de ese año. Fue por estas fechas cuando parece haberse decantado la extraordinaria admiración que en ella despertó Borja tras hacer público su nuevo estado en 1550, al mismo tiempo que el nuevo jesuita imparte su enseñanza espiritual como miembro de la Compañía. Se documenta en 1551 una visita del ya padre Francisco a Toro ${ }^{22}$, donde reside Juana con su sobrino el príncipe Carlos, alternando estancias en Aranda y Tordesillas, donde su abuela, la reina Juana, vive sus últimos años. En mayo de 1552 acude Borja a atender a la anciana reina, que, en su lastimoso encierro, preocupa a todos por su descuido de las cosas del espíritu y del cuerpo ${ }^{23}$, y es convocado también a Toro por la Princesa, a la sazón en los preparativos de su jornada a Portugal, que inciará el 25 de octubre ${ }^{24}$.

Un momento importante en la relación entre Borja y Juana de Austria tiene lugar asimismo durante los escasos catorce meses (diciembre 1552 - marzo 1554) que ella pasó en la corte portuguesa como esposa del heredero de Portugal, destino frustrado

21 Sobre estos episodios cf. ASTRAIN, op. cit. (nota 8), t. I y t. II, cap. V y cap. VII; hace referencia a la especie difundida por esos años de máxima beligerancia de Melchor Cano sobre el presunto carácter deshonesto de la relación entre Borja y la Princesa, que relaciona con la campaña del dominico contra los jesuitas; señala la incidencia de este hecho en la salida de Borja de España, cómo hizo llegar a Felipe II una carta de descargo y cómo el rey optó por no hacer oídos al asunto ni a este mensaje, pero tampoco volvió a relacionarse con el futuro santo. Por lo demás, sobre la dura acción contra el espiritualismo por el inquisidor Fernando de Valdés, cf. BATAILLON, op. cit., 1966 (nota 8).

22 BATAILLON, op. cit., 1952 (nota 8), p. 263; para este episodio y los subsiguientes en la corte de Lisboa se remite a las cartas de Bartolomé de Bustamante a Ignacio de Loyola, Lisboa, 20 de septiembre de 1553, y Córdoba, 29 de octubre de 1553 (Monum. Hist. S. J., Epistolae Mixtae, t. III, p. 500 y ss. y p. 542 y ss.)

23 RODRÍGUEZ VILLA, op. cit., 1892 (nota 9), p. 384-385: AGS, Estado, leg. 89, carta del marqués de Denia al príncipe Felipe, 9 mayo 1552). Recoge también el relato de las visitas de Borja a Tordesillas en 1554, p. 386-393 (AGS, Estado, leg. 109, cartas de Francisco de Borja al príncipe Felipe, mayo 1554), y de los últimos días de la malhadada reina que muere el 12 de abril de 1555 asistida por Borja, p. 395-400 (AGS, Estado, leg. 108, carta de fray Domingo de Soto al secretario Vázquez, 11 abril 1555, y carta del doctor Santa Cara al Emperador, 10 mayo 1555).

24 DANVILA y BURGUERO, op. cit. (nota 9), p. 25-30: documenta la jornada de la Princesa a Portugal, principalmente AGS, Estado, leg. 96 (cartas intercambiadas entre el Emperador, el príncipe Felipe, Luis Sarmiento y Luis Venegas, diciembre 1552). 
por la prematura muerte del príncipe. Esa etapa evidencia el carácter huidizo de la Princesa y sus dificultades de adaptación a su nuevo papel y a la corte gobernada por su tía y suegra, la reina Catalina, tal como informan los embajadores al Emperador ${ }^{25}$. En ese verano de 1553 llega el padre Francisco a Lisboa buscando el afianzamiento de la Compañía en Portugal, y el relato de esta estancia por Bartolomé de Bustamente transmite cómo, frente a la habitual actitud retraída y arisca de Juana, se muestra de modo muy diferente ante Borja, cuya presencia reclama constantemente ${ }^{26}$. Informa también de cómo Borja aprovecha su afición a los juegos de naipes sustituyendo la baraja por otra compuesta de imágenes de virtudes y vicios, cada una acompañada de máximas edificantes; y cómo por Navidad inventa otro entretenimiento para las damas de la corte: la lotería de las virtudes de Nuestra Señora, en que se sorteaban pequeñas oraciones sobre los Gozos de la Virgen que debían recitar en la octava de la fiesta. Ejerce Borja, pues, en la Princesa y entre sus damas una suerte de pedagogía espiritual algo infantil pero también representativa de la desarrollada por los jesuitas.

En 1554, el inopinado vuelco que se produce en la vida de Juana de Austria dará ocasión al proyecto que culminará en las Descalzas de Madrid. Los primeros días de ese año fueron tiempo de gran tribulación: el día 2 de enero muere el príncipe Juan estando ella casi a término de la gestación de su hijo -que será el rey Sebastián-, al que da a luz menos de tres semanas después, el día $20^{27}$. Por esas fechas se pactaba también el nuevo matrimonio del príncipe Felipe -viudo de su esposa portuguesa desde nueve años atrás- con María Tudor, de modo que, ante el inminente viaje del heredero a Inglaterra, el Emperador recurre a Juana como regente y ordena que vuelva a Castilla; firma los oportunos poderes en Bruselas el 31 de marzo y se envía a Luis Venegas de Figueroa, Aposentador Mayor del Príncipe, para atender el traslado de la Princesa de regreso a Castilla que se inicia el 15 de mayo ${ }^{28}$. A fin de mes se encuentran los hermanos en Alcántara, se aposentan juntos en Abadía, en casa de Duque de Alba, y allí se despiden, dirigiéndose Felipe a Coruña, donde embarca el 11 de junio, y Juana a Valladolid, donde permanerá casi todo el tiempo de su regencia. Ejercerá hasta septiembre de 1559 -cuando regresa Felipe, entonces ya rey-, si bien siempre bajo la tutela de su padre, mucho más estrecha desde que este llega a Castilla en septiembre de $1556^{29}$.

Es Venegas de Figueroa, en sus cartas al Emperador sobre los preparativos del viaje de la Princesa, quien aporta interesantes noticias de este momento ${ }^{30}$. Informa de cómo se halla envuelta en un luto de rigor extremado, pasando la vida encerrada

25 Ibidem, p. 42-44: documenta la estancia de Juana de Austria en la corte de Portugal, principalmente en AGS, Estado, leg. 375 y 376 (cartas de Luis Sarmiento al Emperador, a Juan Vázquez y al príncipe Felipe, abril-diciembre 1553).

26 Vid. supra nota 22.

27 DANVILA Y BURGUERO, op. cit. (nota 9), p. 48-49: AGS, Estado, leg. 377.

28 Ibidem, p. 51-54: AGS, Estado, leg. 377 (cartas de Luis Sarmiento y Luis Venegas al Emperador y al príncipe Felipe, enero-junio 1554).

29 Vid. J. MARTíNEZ MILLÁN, "Grupos de poder en la corte durante el reinado de Felipe II: la facción "ebolista" (1554-1573)", en ID. (ed.). Instituciones y elites de poder en la Monarquía Hispana durante el siglo XVI. Madrid, Universidad Autónoma, pp. 137-197.

30 DANVILA Y BURGUERO, op. cit. (nota 9), p. 52: AGS, Estado, leg. 377, s. f., "los puntos que escribia Luis Venegas". 
y en grandes penitencias, y transmite también que le manifestó su deseo de que en la corte le gustaría vivir en algún convento junto a palacio y no salir más que lo imprescindible para despachar. Esta noticia es el testimonio más directo sobre su propósito de disponer de un aposento propio al que poder retirarse, aspecto que será esencial en la concepción del monasterio madrieño que en efecto, como hemos señalado en otras ocasiones, respondió precisamente a tal fin, con su cuarto real y jardines, su iglesia con funciones entre monásticas y aúlicas, pensada también para su propio sepulcro, y la institución de una importante capilla musical, todo de acuerdo al evidente sentido regio que preside este proyecto y en general las obras artísticas de Juana de Austria.

Los informes de Venegas abundan al mismo tiempo en la exacerbada religiosidad de la Princesa que parece acentuarse a partir de ese momento, cabe creer que ante la fractura de su destino previsto como reina de Portugal. Sus actitudes parecen mostrar ecos del espiritualismo reformador europeo de los años veinte y treinta del siglo XVI, rasgos de piedad recogida que recibe seguramente a través de Borja, de quien hay que recordar asimismo su propia derivación hacia un cierto misticismo alumbrado, que es patente durante los años de su virreinato en Cataluña en su estrecha relación con el franciscano fray Juan de Tejeda ${ }^{31}$; este peculiar personaje, característico de cierto alumbradismo en esas fechas, es mencionado, por otra parte, en la citada Cronica de las Descalzas como mentor de sor Francisca de Jesús en Gandía.

Pero el papel sustancial de Francisco de Borja en las decisiones de Juana de Austria se evidencia en los episodios que tienen lugar a su llegada a Castilla cuando, según parece, manifiesta su voluntad de entrar en religión, que vendrá a resultar en una peculiar incorporación a los jesuitas ${ }^{32}$. Cabe relacionar con ello las repetidas entrevistas de Juana con Borja y Araoz en los primeros días de su estancia en Valladolid en junio de 1554, y luego en agosto, cuando vuelve Borja tras breve ausencia en la que deja encargo a Araoz de acudir a palacio con frecuencia ${ }^{33}$. Parece que por entonces Juana está determinada en tal decisión, seguramente poco oportuna dada su posición familiar y política; y digamos que las fuentes dejan traslucir, a pesar de su cautela, los problemas del padre Francisco ante pupila de tan alto rango y actitud voluntariosa, y ante el hecho de que el deseo de la Princesa, además de los importantes condicionan-

31 F. PONS FUSTER, "El mecenazgo cultural de los Borja en Gandía: erasmismo e iluminismo", Estudis. Revista de Historia Moderna, 21 (1995), pp. 23-44. También, LA PARRA, op. cit., 1998 y 2010 (nota 11).

32 Aunque publicadas de antiguo las fuentes jesuíticas, esta cuestión ha quedado en cierta penumbra para la historiografía sobre Juana de Austria, por otra parte bien escasa. Aportación de referencia, con revisión esencial de esas fuentes, a quien sigo: W. SOTO ARTUÑEDO, “Juana de Austria ¿de la Compañía de Jesús?”, en Felipe II y su tiempo. Actas de la V reunión científica de la Asociación Española de Historia Moderna, Universidad de Cádiz, 1999, vol. I, pp. 579-588. La documentación relativa muestra reserva y cautela propias de asuntos espinosos, y de la conducta de la Compañía al respecto, de modo que todo se sustancia en base a conjeturas encadenadas.

33 Ibidem, p. 581: Litterae Quadrimestres ex universis prater Indiam et Brasiliam locis, in quibus aliqui d Societate Iesu versabantur, Madrid, 1894-1932, III, p. 23 (Bustamante a Ignacio de Loyola, Valladolid, 16 junio 1554) y p. 48-49 (Antonio Gou a Ignacio de Loyola, Valladolid, 14 julio 1554). La demanda de su presencia por parte de la Princesa consta también más tarde, en febrero de 1556, cuando escribe a Ignacio de Loyola oponiéndose a que Borja y Araoz salieran de España, apud ibidem: Epistolae Mixtae ex variis Europe locis ab anno 1537 ad 1556 scriptae, Madrid, Institutum Historicum Societatis Iesu, 1898-1901, V, p. 185 (Juana de Austria a Ignacio de Loyola, Valladolid, 7 febrero 1556). 
tes de su persona, chocaba frontalmente con el criterio de Ignacio de Loyola opuesto a aceptar mujeres en la Compañía, como es sabido. Con todo, la Princesa, mediando Borja, debió solicitar efectivamente su incorporación a los jesuitas.

Siguiendo la secuencia de los documentos parece, por un lado, que Juana se hubiera vinculado antes a las franciscanas con algún voto previo (¿quizá en los primeros días de su viudez en Portugal?), porque dan cuenta de gestiones en Roma sobre la "conmutación de aquel voto", según nota de Ignacio a Borja de 26 septiembre de $1554^{34}$. Por otro lado, su petición de adhesión a los jesuitas se deduce del informe, que es remitido también a Borja, como resultado de la consulta extraordinaria celebrada por destacados miembros de la orden en Roma el 26 de octubre de 1554 sobre "el admitir a Matheo Sancho en la Compañia", seudónimo identificado con Juana en base a un comentario de Francesco Sacchini (1570-1625), historiador de la orden, que en el margen de una página de la crónica de Polanco (1555) escribe: "Opinor hanc esse Principem Lusitania Joannam" ${ }^{35}$. Según dicho informe, en aquella sesión se discutió el modo y el grado de vinculación que podía aceptarse en la adhesión de "esta persona, quienquiera que sea, pues con previlegio tan especial, y sola, es admitida en la Compañia", y se determinó, en base a que "fueron admitidas tres personas semejantes al principio", que "podía ser admitida esta persona, y convenia que se admitiese, al modo que se resciven los scholares de la Compañia", esto de acuerdo a las Constituciones y sus matices al respecto, -es decir, según un tipo de voto que vinculaba al solicitante pero no a la orden y por tanto revocable-, señalando por fin que "tenga su admission debaxo de sigillo de secreto y como en confesión porque sabiendose, no fuese exemplo para que otra persona tal disese molestia a la Compañia por tal admission. En lo demas esta persona no tendra para qué mudar habito, ni casa, ni dar demostracion alguna de lo que basta que tenga entre sí y Dios nuestro Señor"36. Así pues, no existe prueba documental de voto alguno de Juana de Austria, pero es de suponer que realizase en efecto ese compromiso personal de adhesión a la orden como "escolar", en todo caso en privado y "como en confesión", según se dice.

Es en este contexto en el que nace la fundación monástica de la Princesa. Si bien el citado testimonio del aposentador Venegas da cierto apoyo a las crónicas históricas de las Descalzas sobre que Juana la habría concebido en Portugal inspirada en las franciscanas de la Madre de Dios de Setúbal, la idea debe tomar cuerpo ya en Castilla, y la parte de Francisco de Borja en ello se revela mucho más sustancial que la mera aprobación de la iniciativa que esas fuentes sugieren, porque fue indudablemente él quien pudo orientar la empresa, tomándola de su mano, solventando la cuestión

\footnotetext{
34 Ibidem, p. 583: "Una vuestra sobre scritta para mi solo y sub sigillo secrete, me dio el Mtro Nadal: y hase dado orden que, sin nombrar la persona, se pidiese a S. S. la conmutación de aquel voto; y oy Mtre. Polanco dio una memoria a un cardenal desta conmutation, aunque él no save a quien ha de servir; y no ay duda sino que luego se concederá. Y a la causa os aviso para que podays passar adelante con aquella persona", Epistolae Mixtae ex variis Europe locis ab anno 1537 ad 1556 scriptae, Madrid, Institutum Historicum Societatis Iesu, 1898-1901, VII, p. 685.

35 Ibidem, p. 585: Vita Ignatii Loiolae et rerum Societatis Iesu historia, auctore Joanne Alphonso de Polanco, eiusdem Societatis sacerdote, Tomus Quintus (1555), Madrid, 1897, p. 47.

36 Ibidem, p. 584: Sancti Ignatii de Loyola Epistolae et Instructiones, Madrid, 1903-1911 (reimpr. Roma, 1964-1968), VII, pp. 686-688.
} 
de los votos religiosos de la Princesa y dirigiéndola hacia las clarisas de Gandía, y en concreto a la autoridad y experiencia de su tía Isabel de Borja, sor Francisca de Jesús, que había sido su abadesa entre 1533 y 1548. Sor Francisca andaba en ese momento empeñada además en una nueva fundación que le había permitido salir de Gandía, donde la presencia de su familia le venía resultando demasiado onerosa; en 1552 había iniciado esta fundación en Casalarreina (La Rioja), con el patrocinio de la duquesa de Frías, doña Juliana Velasco y Aragón, esposa del Condestable de Castilla y también pariente de los Borja, pero el proyecto se había malogrado por la muerte de la duquesa, de modo que es en ese punto donde el propio Borja debió ver, de acuerdo con las inquietudes de su tía, la ocasión para reconducir la incipiente comunidad hacia la fundación de la Princesa ${ }^{37}$.

A partir de ahí el proceso de constitución del monasterio se prolongó durante los años de su regencia. Lo principal del proceso fueron las gestiones para instalarlo en Madrid, decisión que Juana parece haber determinado por motivos -como también insisten las crónicas- de vinculación sentimental con el edificio elegido: el suntuoso palacio con jardines y amplias huertas del tesorero Alonso Gutiérrez, junto al Monasterio de San Martín, que por entonces era propiedad de su viuda e hijos; Gutiérrez había sido un opulento hombre de negocios de origen converso que había llegado a ocupar varios cargos en la administración hacendística del Emperador, entre otros el de tesorero de la Hermandad, apelativo con que fueron conocidos en Madrid el personaje y la casa ${ }^{38}$. En esta gran mansión del Tesorero se había aposentado la Emperatriz Isabel en 1535 con ocasión del natalicio de Juana, justamente en el momento en que su construcción se remataba, y permaneció allí con sus hijos hasta la primavera siguiente. Además, en los años posteriores a la muerte de la Emperatriz este palacio madrileño también había servido como residencia para la infanta y su hermana mayor, María, durante su infancia, entre 1542 y 1546. Así pues, en efecto, el lugar tenía evidentes vinculaciones sentimentales para la Princesa, pero hay que pensar que, además de estos motivos, se tuvieran en cuenta las características e idoneidad del sitio para los fines que se pretendían, esto es, como hemos dicho, no solo la instalación del monasterio sino la disposición del cuarto real, al que se proponía añadir la correspondiente iglesia monástica que a su vez debería funcionar también como capilla aúlica y regia sede funeraria. Y tampoco dejarían de verse como circunstancias muy oportunas para adquirir el edificio la precedente relación de la familia real y de la propia Princesa con sus propietarios. En definitiva, las gestiones consistieron, por un lado, en resolver la compra de esta finca a los herederos de Alonso Gutiérrez, transmisión que implicaba la desvinculación de la finca del mayorazgo instituido sobre ella, por entonces administrado por María de Pisa, su viuda; y por otro, en procurar fondos dinerarios, como atestigua la citada petición a las Cortes de Castilla de 1555 de un servicio a la Princesa para la fundación que emprendía, dotación que se aprobó en veinte mil ducados.

La comunidad se formó en 1557 con un grupo de seis monjas encabezado por sor Francisca de Jesús que llegan a Valladolid a fines de septiembre, instalándose en una

37 AMORÓS, 1961, op. cit. (nota 14), p. 256-260.

38 Para esto y lo que sigue, $c f$. TOAJAS, op. cit., 1999, 2005, 2013 (nota 5). 
"casilla de prestado" 39 . El grupo procedía de las clarisas de Gandía, que se constituía así como casa madre de la nueva comunidad, aunque venían de La Rioja ${ }^{40}$. Sor Francisca murió solo un mes después de su llegada a Valladolid, el 28 de octubre, quedando entonces como abadesa sor María de Jesús, Francisca Enríquez de Sandoval, que era su prima, hija de Bernardo de Sandoval y Francisca Enríquez de Luna, marqueses de Denia, bajo cuyo mandato se trasladaría la comunidad a Madrid en 1559. En adelante la presencia rectora de la familia Borja en las Descalzas se mantuvo largamente, como ya se apuntó antes: muerta también esta última enseguida, la tercera abadesa será Ana María de Borja y Castro-Pinós, sor Juana de la Cruz (1535-1601), que era una de las hermanas menores de Francisco de Borja y bajo cuyo mandato se produce la definitiva instalación de las monjas en el palacio del Tesorero el 16 de agosto de 1559 y la posterior inauguración solemne de la iglesia el dia de la Concepción de la Virgen de 1564. Al mismo tiempo, entre las monjas incorporadas a la comunidad inicial se cuentan otras dos hermanas de Francisco de Borja: María de Borja, Sor María de la Cruz (1513-1569) y Ana de Borja, Sor Juana Evangelista (1514-1568); en la siguiente generación, sus nietas: dos hijas de Carlos de Borja, V duque de Gandía, Sor Magdalena de Jesus (1564-1593) y Sor Juana de la Cruz, que sería la cuarta abadesa de las Descalzas; y dos hijas de su hermano Juan de Borja: Francisca, Sor María de los Angeles, incorporada al monasterio en 1568 , y otra sor Juana ${ }^{41}$. Todas ellas habían ingresado inicialmente en Santa Clara de Gandía de donde pasan al nuevo monasterio madrileño, que resulta así una extensión de aquel en todos los sentidos y también en cuanto a su dependencia de la familia ducal.

En este sentido añadamos por fin que la constitución de las Descalzas es fiel reflejo de la relación del ducado con las clarisas de Gandía, que se remontaba a los días de la creación del título y a aquella efímera comunidad observante inicial, como ya vimos. Sin embargo, ese especial patrocinio se produce tras la adquisición del título por el cardenal Rodrigo Borgia para su hijo (1485), y para entonces en un segundo momento de la historia del monasterio, que había sido refundado poco antes (bula Paulo II, 1465) por don Luis de Vich, mayordomo de Juan II, y antiguo administrador del Ducado y del Marquesado de Denia, con monjas del Monasterio de Lezignan (Provenza), de la reforma coletina. Esta reforma específicamente femenina, promovida por Colette Boylet (Corbie, 1381-Gante, 1447), forma parte de los movimientos regeneracionistas en el franciscanismo desde fines del siglo XIV; emerge simultáneamente a la opción observante y a ambos grupos se les aplicará la denominación descalzas ${ }^{42}$.

39 Cronica..., op. cit. (nota 3), f. 2v; también fr. J. CARRILLO, Relacion historica de la Real Fundación del Monasterio de las Descalzas de Santa Clara de la Villa de Madrid, con las vidas de su Fundadora y de la Emperatriz María, su hermana, Madrid, 1616, f. 21r y 21v.

40 AMORÓS, 1961, op. cit. (nota 14), p. 256-260, para este y los datos que siguen al respecto.

41 Para estos datos también M. L. SÁNCHEZ HERNÁNDEZ, Patronato regio y órdenes religiosas femeninas en el Madrid de los Austrias: Descalzas Reales, Encarnación y Santa Isabel, Madrid, F.U.E., 1997, p. 363-364.

42 Vid. supra, nota 14, y AMORÓS, 1960, op. cit., (nota 14), p. 465-470: la reforma coletina consistió en la adopción de la llamada primera regla de Santa Clara (1253), sin las concesiones de Urbano IV (1263), con unas constituciones propias de la nueva fundadora instituidas en su primer monasterio en Besançon, en 1410; a su muerte en 1447 había realizado dieciocho fundaciones desde la Provenza a Flandes. Por su parte, la observancia en España arranca de Santa Clara de Tordesillas en 1380, según Amorós (p. 451-453), pero el primer 
Santa Clara de Gandía se convierte así en el primer monasterio hispano de esta obediencia -hecho siempre muy destacado también en las crónicas de las Descalzas de Madrid-y estará bajo el gobierno de tres sucesivas abadesas francesas hasta 1507.

El asiento de la nueva familia ducal comportará importantes cambios en Gandía, y en este monasterio, sobre todo a través de la duquesa María Enríquez de Luna, viuda sucesivamente de los dos primeros duques, Pedro Luis $(+1488)$ y Juan $(+1497)$, como vimos. Esta mujer, tras sus atribulados y breves matrimonios, además de administrar el ducado durante la minoridad su hijo, -firme defensora de sus derechos incluso frente a su suegro el papa, como también se ha visto-, ejercerá en Gandía además un importante patronazgo religioso que revela su inclinación a la vida de piedad, promoviendo la construcción de la colegiata con una espléndida dotación para su clero, $\mathrm{y}$, más importante para lo que nos ocupa, sosteniendo el monasterio y cultivando estrecha relación con él. Lo frecuenta con familiaridad y vela por la generosa limosna de 100 ducados anuales, establecida por el segundo duque a su partida para Roma en $1496^{43}$. En 1511, una vez casado su hijo con una nieta del rey Fernando (1509), nacido también ya un nuevo heredero -su nieto Francisco de Borja en 1510-, y habiendo profesado en el monasterio su hija Isabel -sor Francisca de Jesús- en ese mismo año, ella lo hará al siguiente convirténdose en sor Maria Gabriela.

La protección a las clarisas de Gandía será creciente con el tercer duque, Juan de Borja, cuya madre y hermana viven en él; pero los lazos se estrecharán aun más porque, entre la larga prole de dieciocho vástagos que tuvo en sus dos matrimonios, el monasterio se iría ocupando con sus propias hijas: tres del primero, María, Ana e Isabel, y otras dos de las habidas en el segundo, María y Ana María; las primeras son las que saldrán con su tía a Casalarreina, aunque solo Ana la sigue a las primeras descalzas de Valladolid, y la última será la tercera abadesa de las Descalzas de Madrid. No es de extrañar, pues, que don Juan encarezca el cuidado y el sostén del monasterio en su citado testamento: "Y cuanto podemos, recomendamos las dichas monjas a nuestro sucesor el Duque y señor de nuestro mayorazgo y a los sucesores de aquel, descendientes nuestros, teniendo por muy cierto que, según la obligación que de aquella casa tenemos, adonde nuestro señor Dios tanto es servido el dicho nuestro sucesor la ha de tener por muy recomendada, proveyendo, honrando y sirviendo al dicho monasterio mejor de lo que nos les podiamos rogar y recomendar a él y los que seran nuestros sucesores". En efecto, así lo cumplirá su hijo, Francisco de Borja, cuya descendencia, por lo demás, continuará bien presente en Santa Clara y en las Descalzas de Madrid: su hija pequeña, Dorotea, ingresará en Gandía, aunque muere

monasterio femenino observante bajo la I Regla fue Santa Isabel de los Ángeles en Córdoba, 1489; la reforma generalizada se produce en el reinado de los RRCC bajo la égida de Cisneros en 1493. Por su parte, la reforma coletina asentada en Gandía se extenderá, fundándose en los siguientes cincuenta años otro seis monasterios: Gerona, 1488; Setúbal, 1496; Valencia, 1497; Castellón de Ampurias, 1505; Alicante, 1518, y Casalarreina, fundación iniciada en 1555, pero frustrada por la muerte de su patrocinadora, que da lugar a las Descalzas de Madrid. Vid. también A. GARCÍA SANZ (coord.), Las Descalzas Reales: orígenes de una comunidad religiosa en el siglo XVI, Madrid, Patrimonio Nacional-Fundación Caja Madrid, 2010.

43 AMORÓS, 1961, op. cit. (nota 14), p. 230-231: según el testamento del tercer duque, Juan de Borja, otorgado en Gandía en 28 febrero 1538, en Monumenta Historica Societatis Iesu, I, 78. 
adolescente en 1552 sin haber profesado, y, de sus nietas, una profesará allí y cuatro, en el monasterio madrileño.

\section{La Visitatio sepulchri de Santa Clara de Gandía y las Descalzas de Madrid}

Tales antecedentes permiten afirmar que lo que se hace en las Descalzas de Madrid en los días de la fundación debe relacionarse necesaria y directamente con las cosas de Gandía, y así lo evidencia la capilla de Cristo.

Es interesante al respecto recoger en primer lugar un testimonio sobre la existencia en las clarisas gandienses de dos capillas de especial significación cuyo correlato se encuentra exactamente en las Descalzas de Madrid, ambas entre lo más antiguo de este monasterio: la capilla de Nazaret y esta del Cristo que nos ocupa. Se trata de una relación de la jornada que en 1586 (enero-febrero) realizó a Valencia Felipe II con sus hijos, el príncipe Felipe y la infanta Isabel Clara Eugenia, que incluyó una visita a las clarisas de Gandía; en ella se narra cómo la infanta pidió pasar a la clasura, donde departió con la comunidad, y "haviendo pasado como media hora, tocaron las Guardas del Rey a la puerta de la iglesia del monasterio como haciendo señal de que el Rey venía, y entendiendo la Infanta que su Magestad venia para llevarsela (...) diose gran prisa por ver la capilla del Sepulcro y de Nazareth, donde arrodillada con mucha veneracion, hizo oracion a las imágenes sagradas que son alli veneradas" ${ }^{44}$. Por otra parte, hay que llamar la atención también sobre las advocaciones de estas capillas por cuanto se refieren a los dos tipos de representaciones litúrgicas con mayor arraigo en la tradición europea medieval: los autos de Navidad y los de la Pasión ${ }^{45}$.

Ese referente, ya significativo respecto al origen de la capilla del Cristo de las Descalzas, remite además a un ritual litúrgico gandiense que la tradición local ha creído precisamente instituido por Francisco de Borja en 1550: una ceremonia procesional de Semana Santa que involucra a la colegiata y al monasterio de las clarisas, y es una dramatización alrededor de la muerte de Cristo y su resurrección. Este rito debe derivar de un privilegio de que disfrutaban las clarisas de Gandía para tener expuesto el Santísimo -la hostia consagrada- durante los días de la Semana Santa que rememoran esos hechos, es decir, entre Viernes Santo y el Domingo de Resurrección, privilegio extraordinario que fue transferido también a las Descalzas de Madrid. De todo ello informa la crónica de José Llopis de 1781 ya citada: "Nuestro Santísimo

44 Crónica del Real Monasterio de la Seráfica Madre Santa Clara de la Ciudad de Gandía. Escrita por el padre Fr Josef Llopis... confesor ordinario del mismo santo monasterio, mss., Gandía, 28 de noviembre de 1781, Archivo de Santa Clara de Gandía (tomo I, p. 75-78), en AMORÓS, 1961, op. cit. (nota 14), p. 274; se remite además a un acta notarial sobre la visita real publicada por P. SANZ Y FORÉS, Memorias de Gandia, 1890, recogida también en $M H S I, I$, pp. 330-333.

45 Sobre la capilla de Nazareth en las Descalzas de Madrid, de peculiar estructura a modo de cobertizo exento con techumbre a dos aguas, no hay noticia concreta de su construcción; M. T. RUIZ ALCÓN, "Descalzas Reales. La capilla de la Dormición y la Casita de Nazaret”, Reales Sitios, 22 (1969), pp. 53-64, y A. RODRÍGUEZ GUTIÉRREZ DE CEBALLOS, “Arte y mentalidad religiosa en el museo de las Descalzas Reales", Reales Sitios, 138 (1998), pp. 13-24, se limitan remitirse a la citada crónica de fr. Juan Carrillo sobre la devoción de la Virgen de Loreto, cuyo santuario alberga una similar muy venerada por creerse la original del nacimiento de Jesús, milagrosamente depositada allí. 
Padre Alejandro VI para expresar su paternal benevolencia en el más alto grado a estas sus amadas religiosas, de este santo monasterio de Gandía: les concedió uno de los más singulares privilegios, que hacen venerable, y gloriosa esta santa casa. Redúcese este privilegio a que conserven a Christo Señor Nuestro sacramentado desde el Jueves Santo por la mañana, hasta el Domingo de Resurrección por la mañana, en el monumento. He dicho uno de los más singulares privilegios porque es cierto, que en quanto he corrido, que es mucho, no le he visto practicar en parte alguna. Sólo se hace la misma ceremonia en el monasterio de las señoras Descalzas Reales de Madrid; pero no es de estrañar; porque como estas señoras religiosas son hijas de las de Gandía: quizá éstas, como fundadoras de aquel monasterio matritense impondrían a sus moradoras en la práctica de este raro privilegio" 46 .

La crónica de Llopis también describe esa ceremonia procesional y se hace eco además de esa tradición local que suponía al propio Francisco de Borja instaurador de este privilegio y aun autor de la composición musical que la acompañaba, que se habría realizado ex profeso en esa fecha. Sin embargo, el ilustrado clérigo pone precisamente en cuestión tales supuestos, ya que lógicamente debería ser anterior según esa referencia al papa Borja. Interesa la transcripción de lo sustancial porque es la fuente de referencia para todos los estudios posteriores y también para la liturgia que hemos de relacionar con la capilla del Cristo de las Descalzas:

“(...) Mas, en orden a saber el personage que impetró este indulto de la Silla Apostóhca: no es tan fácil, como les pareció a algunos. El Padre Thomas Serrano dice estas solas formales palabras: «El día primero de agosto de 1550, estando ya el santo duque (don Francisco de Borja) para partirse a Roma, y dejar de una vez para siempre a Gandía: quiso dar el último testimonio de su piedad, y entrando en la sala capitular de su insigne colegial a tiempo, que estaban en ella juntos en cabildo sus ilustres capitulares, les dijo el último adiós, y instituyó diferentes obras pías; cuya memoria se halla en el archivo de esta iglesia. Y como desde su mismo nacimiento, y después en todos los pasos de su vida havía debido tanto al Real Monasterio de Santa Clara: no pudo olvidarse de él en este último acto. Uno de los privilegios, que hacen venerable la real casa, y al parecer, concedido por el señor Alejandro VI, es que se conserve en él el Cuerpo del Señor en el monumento hasta la mañana de Pasqua. Para que esta ceremonia se hiciese con más solemnidad, instituyó el santo duque, que el Viernes Santo, acabados en la colegial los oficios, pasasen de ella a Santa Clara dos canónigos, y dos sorchantres [sic] con quatro beneficiados a pasar el Cuerpo del Señor del monumento mayor, en donde havía estado desde el Jueves, a otro menor, que en la misma iglesia se havía, para que en él se conservase hasta la mañana de Pasqua. Instituyó asimismo, que al rayar del alba de la mañana de la Resurrección, fuese todo el cabildo en procesión al monasterio de Santa Clara, y sacando el Cuerpo del Señor de dicho monumento, cantando himnos, y motetes, que el mismo santo duque compuso, y puso en solfa, según es tradición, lo llevase en procesión por las calles vecinas al monasterio, y al fin de ella, dejándolo encerrado en el trasagrario, se bolviese en la misma forma a la colegial».

46 Crónica del Real Monasterio (...) de Gandía, op. cit. (nota 44), Libro I, cap. XIII, f. 66-69, según transcripción de J. M. VIVES RAMIRO, "La pervivencia de la Visitatio Sepulchri de Gandía (Valencia) (15502004)”, Anuario musical, 59 (2004), pp. 23-84, p. 28; también de aquí la transcripción que sigue. 
Hasta aquí el padre Serrano, de cuyo contexto no se puede inferir, como quieren algunos, que san Francisco de Borja impetrase de Alejandro VI este privilegio. (...) Es preciso decir, que el expresado privilegio le [sic] solicitó, o esta religiosa comunidad, o alguno de los progenitores de San Francisco de Borja: Mas ni aun esto lo podemos saber con certitudumbre [sic], a causa de que cierta religiosa cocinera de este Real Monasterio echó muchas bulas pontificias, privilegios reales, y otros muchos papeles en el horno de la cocina, pensando, que no serían de alguna importancia: y es verosímil, que entre ellos se quemase también la bula de la concesión de este singularísimo privilegio. Por lo que querer saber quién impetró dicho privilegio, es lo mismo que querer adivinarlo. Mas no será superfluo escribir aquí las ceremonias, con que se practica en esta santa casa, con el concurso de ambos ilustres cabildos, eclesiástico, y secular, el Domingo de la Resurrección de Jesuchristo por la mañana.

Al rayar del alba de dicha mañana salen en procesión de la colegiata los señores canónigos, y los del ilustre magistrado con la circunspección, y modestia, que pide una función tan devota. El señor cabiscol, o chantre va revestido con alba, estola y capa pluvial, asociado de diácono, y subdiácono, que también son canónigos de la misma colegiata. Luego que entran en la iglesia de este santo monasterio, la música de dicha colegiata canta con voces sonoras el versículo del responsorio séptimo del oficio del día, que dice así: Venite, et videte locum, ubi positus erat Dominus. Luego después uno de los monacillos vestido de ángel con una palma en la mano, sube al monumento con otros tres monacillos vestidos también de vestiduras blancas, y con coronas en sus cabezas, representando a las tres Marías, que fueron muy de mañana al monumento de Christo Señor Nuestro, con vasos de aromas, como dice san Marcos Evangelista, para ungir al mismo Jesuchristo. Como como (sic) estos tres van en busca del Señor al monumento, luego que el que representa al ángel, llega a la urna, hace el ademán de ver ver (sic) si Christo está en aquel como sepulcro: y dando a entender, que ya ha salido de él, se va bajando, y en la primera grada superior del monumento entona en voz algo baja: Surrexit Christus. Desciende después otras dos gradas, y en voz algo más alta, entona por segunda vez: Surrexit Christus. Baja otras dos gradas, y canta en tono más alto: Surrexit Christus.

Haviendo cantado estas palabras el monacillo, que representa al ángel, prosigue la música cantando con harmoniosas sonoras voces el Alleluya; y tirando al mismo tiempo un hermano donado la cortina, se descubre el Santísimo Sacramento. Luego se lo da el canónigo diácono al dicho preste, y se hace la procesión con la devoción acostumbrada: la qual concluida, se buelven ambos ilustres cabildos a la colegiata."

Esta crónica es la base para el estudio de esta ceremonia que aborda por primera vez Mariano Baixauli a inicios del siglo XX, inducido por el hallazgo de otro clérigo investigador, en el archivo de la colegial de Gandía, de "una misa a cuatro y los motetes que se cantaban en la procesión del dia de Pascua de Resurrección con motivo de un así como auto sacramental que representaba la Resurrección del señor, y tenía lugar antes de descubrir el Santísimo; todo ello instituido y fundado en el Convento de Santa Clara por San Francisco de Borja en 1550"47. Pretendiendo sustanciar su

47 M. BAIXAULI, «Las obras musicales de San Francisco de Borja conservadas en la insigne colegial de Gandía», Razón y Fe, IV (1902), pp. 154-170 y 273-283, la cita, p. 155. El propósito de este clérigo es en buena medida reivindicar la recuperación de ese rito, que se había venido celebrando hasta 1865 , cuando fue suprimido por el arzobispo de Valencia monseñor Barrio. Poco después da noticia de esta ceremonia, aunque 
atribución al santo duque, analiza aspectos musicales de estas piezas que transcribe según la copia más antigua que dice haber encontrado, datada en 1697, pero también aporta un registro de las Actas Capitulares de la Colegiata de Gandía, fuente importante que interesa en ambos sentidos, por aclarar la intervención de Borja y por certificar la descripción del ritual:

"Dicho día (4 de Agosto de 1550) el reverendo Cabildo capitularmente congregado á petición del ilustre S. Duque D. Francisco de Borja, precediendo diversas prácticas y consultas, y no pudiendo conducir á Su Señoría, aceptaron y ofrecieron de hacer decir, celebrar y poner en ejecución por las obras pías antes escritas y las muchas obligaciones que nuestra Iglesia y todos en particular deben á Su Señoría. Primeramente se han de celebrar doce Misas, etc. (...)

Item, deja Su Señoría cinco sueldos, que se distribuyan entre dos Revdos. Canónigos, dos Sochantres y cuatro Capellanes, á quien tocare por turno, los cuales el Viernes Santo, acabado el oficio en nuestra Iglesia, han de ir á Santa Clara y pasar el Santísimo cuerpo de N. S. Jesu-Crísto del monumento mayor y encerrarlo en el otro, de donde se ha de sacar el día de la Santísima Resurrección, pagando á cada Canónigo nueve dineros (18 mvds.), á los Sochantres ocho dineros, á los Capellanes á seis dineros, y dos dineros para velas.

Item, quiere Su Señoría que el día de la Santísima Resurrección, al alba, se vaya en procesión general al Monasterío de Santa Clara, vistiéndose el Revdo. Deán para asistir de Preste, ó en su lugar el Revdo. Chantre, ó por él el Revdo. Canónigo Pbro. á quien por turno le tocare, vistiéndose Diácono y Subdiácono, Canónigos que les tocare por turno, y el Preste, que estará revestido, ha de sacar el Smo Cuerpo de N. S. Dios del monumento donde estará encerrado, y con las ceremonias acostumbradas, cantando himnos, versos y motetes y oraciones; según la forma hecha para este efecto, se ha de sacar de dicho Monasterio y llevarle por los lugares acostumbrados y volverle á aquél, y de allí en procesión se ha de volver el Revdo. Clero á nuestra Iglesia, y á la puerta de aquélla, nuestro bolsero les ha de pagar sus porciones, es á saber: que para dicha procesión deja Su Señoría V libras, de las cuales se han de pagar cinco á los que llevan los órganos (á los tañedores), que han de seguir todo el tiempo la procesión, y ocho para la enramada de mirto, y espadaña, y se ha de comprar una vela para cada eclesiástico, y que quede para ellos, además de las porciones ordinarias; y la restante cantidad se ha de dividir entre todo el Clero que personalmente intervenga en el acto, terceando entre Canónigos y Capellanes.

Item, quiere Su Señoría que nuestro Revdo. Cabildo haga hacer en Santa Clara el monumento pequeño, y pague el aceite que será menester y se quemará para iluminación del Santísimo Cuerpo de Jesu-Cristo, que allí estará encerrado hasta el día de la Resurrección; que suelen arder allí doce lámparas noche y día, y deja veinticinco libras de renta" 48 .

con alguna variación en su descripción, J. RUIZ DE LIHORY [Barón de Alcahalí], La música en Valencia. Diccionario biográfico y crítico, Valencia, Tipografía Doménech, 1903 [reed. de 1987], pp. 192-193.

48 BAIXAULI, ibidem, p. 281-282 y p. 279-280: Códice 2, Libre I de Recorts; incluye también transcripción del texto original en valenciano, variando la puntuación textual entre ambas versiones. Su transcripción es la de referencia porque esta documentación está perdida, según parece durante la última guerra civil. 
En su análisis musical, Baixauli señala su estilo contrapuntístico y la proximidad de varias partes a modos flamencos practicados de la corte del Emperador, por lo que cree que los motetes son sin duda de Borja y, en consecuencia, "la misa también lo será"; del mismo modo, del acta capitular deduce que tales mandatos aluden a la institución misma de la ceremonia y a la autoría de Borja, que pretende certificar sobre la frase "según la forma hecha para este efecto". Sus afirmaciones vienen condicionadas sin duda por la tradición local y por su enfoque hagiográfico respecto al santo duque, apoyándose también en sus biógrafos sobre sus conocimientos musicales y su afición a la música ${ }^{49}$. De ese modo, aunque se basa en Llopis, no repara en las puntualizaciones que este aporta, mucho más ajustadas que las suyas, y en fin, su interpretación del acta capitular que publica pasa por alto el que aluda repetidamente a un rito preexistente diciendo que se mantengan "las ceremonias acostumbradas", con sus himnos, motetes y oraciones, al sacar el cuerpo de Cristo "de dicho Monasterio y llevarle por los lugares acostumbrados", como investigaciones más recientes también han argumentado ${ }^{50}$.

Por lo demás, las disposiciones de Francisco de Borja para la ceremonia se producen en el contexto de la gran actividad que despliega en ese verano de 1550, en los días en que ultima los preparativos para su mancha de Gandía, "per quant és mon intent (...) de viure y servir a Nostre Señor Deu de aquí al devant (...) per lo qual effecte me tinc de partir de prest per a Roma", como dice en su testamento, otorgado el 26 de agosto ante el escribano de Gandía Onofre Pérez de Culla ${ }^{51}$. Es entonces, atendiendo también a sus obras pías, cuando deja ordenado al cabildo de la Colegiata un estipendio expresamente dedicado a esa celebración cuya conservación les encomienda tan encarecidamente. En todo caso, si bien hay que poner en duda la autoría que se le atribuye, queda manifiesto el apoyo del duque jesuita a esas ceremonias y, respecto a nuestro argumento aquí, también abunda esto en los motivos de su transposición a las Descalzas de Madrid.

Al margen de que la composición musical en las copias conservadas muestre características propias del siglo XVI, la ceremonia misma remite sin duda a una tradición muy anterior, no ya local sino en los reinos hispanos y en el occidente europeo en general, con especial desarrollo en forma de dramatización litúrgica en el siglo XV. Y respecto a la propia Gandía, la referencia al privilegio papal para exponer el santísimo en los días de viernes santo, señalada por Llopis como procedente de Alejandro VI, es dato es muy coherente con el momento en que se afianza el patrocinio ducal hacia el Monasterio; lo pudo otorgar el papa en los primeros días de su ponti-

49 Se remite a Ribadeneira, Nieremberg y la manuscrita de Dionisio Vázquez, precisamente localizada en el Convento de Santa Clara, vid. supra nota 10.

50 J. M. VIVES RAMIRO, "La Visitatio Sepulchri de Gandía”, en S. LA PARRA LÓPEZ et al., "Visitatio Sepulcri' de San Francisco de Borja, Gandía, CEIC Alfons el Vell, 1998, p. 145-153; ID., op. cit. (nota 46); M. C. GÓMEZ MUNTANÉ, "Francisco de Borja y la música: autor y promotor", en Francesc de Borja (15101572), home del Renaixement, sant del barroc [actas simposio 2010]-Revista Borja, 4, 2012-12, pp. $517-528$.

51 Citado por S. LA PARRA LÓPEZ, "Trescientos años de la Visitatio en Gandía (1550-1865)", en: S. LA PARRA LÓPEZ et al., 'Visitatio Sepulchri'de Sant Francesc de Borja, Gandía, CEIC Alfons el Vell, 1998, pp. 97-126, p. 107 (según transcripción de J. IBORRA, en Miscel.lania Josep Camarena, Gandía, CEIC Alfons el Vell, 1997, pp. 43-67, sobre la publicada en MHSI, I, pp. 537-566). 
ficado, durante la breve estancia en Gandía de su hijo, el segundo duque, cuando se está afianzando su casa allí, o quizá ya a través de su viuda María Enríquez, la gran benefactora del monasterio desde que regresa de Roma a la muerte de su marido en 1497. A mi juicio, ella, con su activa protección del monasterio en que después ingresaría, parece la inductora más plausible de la instauración de ese ritual en el refundado convento de clarisas coletinas, y también cabe pensar que esa primera comunidad francesa hubiera traído consigo este uso, que entonces fuese formalizado en Gandía.

La forma de esta ceremonia, de acuerdo a esa consueta conservada, y tal como la describen Llopis y Baixauli, responde a una representación de larga raíz medieval conocida como Visitatio Sepulchri, cuyo origen son los ritos de la Depositio Crucis y la Elevatio Crucis, y el tropo Quem quaeritis ${ }^{52}$. Se remite por tanto a un tipo de drama sacro del que la historiografía especializada recoge indicios hasta la Alta Edad Media, formando parte de las dramatizaciones que se consideran puntos de origen del teatro europeo y que se desarrollan alrededor de los hechos más significativos para la cristiandad: el nacimiento de Jesús -Navidad-y su muerte y resurrección -Semana Santa y Pascua-. En torno a estos dos tiempos del año y a la liturgia del culto asociada a ellos, tiene lugar, como es sabido, la incorporación de estos tropos, pequeñas piezas cantadas que de alguna manera glosan los textos establecidos para los diferentes momentos de la liturgia, enriquecen su percepción por los fieles y, sobre todo, dan pie a la práctica de cierta escenificación en el rito, puesto que, junto a prosas y música progresivamente más elaborados, aparecen personificaciones de los actores del drama y se ensancha el espacio físico de la liturgia, utilizando diferentes lugares concretos a modo de escenario para la acción, tanto dentro y como fuera de la iglesia ${ }^{53}$.

En los reinos hispanos la vigencia de estas representaciones es de gran vitalidad, apareciendo tres modelos fundamentales del drama litúrgico: los de navidad -Officium pastorum, sobre el nacimiento, y Ordo stellae, sobre los Reyes Magos-, y el de Pascua, la Visitatio Sepulchri, sobre la muerte y resurrección de Cristo $^{54}$. Dentro del gran debate de los especialistas respecto a la naturaleza y niveles de las dramatizaciones, entre lo paralitúrgico, lo parateatral y lo propiamente teatral, interesa señalar cómo, en esa larga tradición del drama litúrgico en relación a la Semana Santa, la

52 Cf. como estudios de referencia: K. YOUNG, The Drama of the Medieval Church, Oxford, 1933; O. B. HARDISON, Christian Rite and Cristian Drama in the Middle Ages: Essays in the Origin and Early History of Modern Drama, Baltimore, The Johns Hopkins University Press, 1965; E. K. CHAMBERS, The Medieval Stage, Oxford, Oxford University Press, 1978; J. STEVENS, Words and Music in the Middle Ages. Song, Narrative, Dance and Drama, 1050-1350, Cambridge, 1986, y L. ALLEGRI, Teatro e spettacolo nel Medioevo, Roma-Bari, Laterza, 1988.

53 La incidencia del drama litúrgico en las representaciones artísticas fue planteada por E. MÂLE, L'art religieux de la fin du Moyen Age en France, Paris, 1925 ( $1^{\mathrm{a}}$ ed. 1908), pp. 35-84. Vid. también, para un tema más concreto, E. C. PARKER, The Descent of the Cross. Its relation to the extra-liturgical 'Depositio'drama, New York-London, Garland Publ., 1978.

54 Para lo relativo a España: Richard B. DONOVAN, C.S.B., The liturgical drama in medieval Spain, Toronto, Pontifical Institute of Mediaeval Studies, 1958; V. GARCÍA DE LA CONCHA, "Dramatizaciones litúrgicas pascuales de Aragón y Castilla en la Edad Media", en Homenaje a don José María Lacarra de Miguel en su jubilación del profesorado. Miscelánea. V, Zaragoza, 1977, pp. 153-175; E. CASTRO, Introducción al teatro latino medieval. Textos y públicos, Santiago de Compostela, 1996; EAD., Tropos y troparios hispánicos, Universidad de Santiago de Compostela, 1991, y EAD., Teatro medieval. I. El drama litúrgico, Barcelona, Crítica, 1997. 
representación en origen no versa sobre la narración del suplicio y muerte de Jesús, sino que va asociada a la celebración de la Pascua, esto es, a la Resurrección. Los testimonios más antiguos, documentados en el occidente europeo desde el siglo X, dan cuenta del ritual que tenía lugar durante la liturgia de esos días, en que el viernes se colocaba una cruz en un lugar ad hoc (depositio), que así viene a simbolizar el sepulcro, y se retiraba el domingo de la Resurrección (elevatio) simbolizando la victoria de Cristo sobre la muerte, ritos pronto enriquecidos con la inclusión del tropo Quem quaeritis (¿a quién buscais?), esto es, la alusión a la visita de las Marías al sepulcro vacío como testigos de la resurrección, punto de partida para un ritual paralitúrgico que incorpora la representación del episodio mismo o Visitatio Sepulchri. Y cabe añadir también cómo la figura de la Magdalena juega un significativo papel en las dramatizaciones progresivamente más narrativas y espectaculares (siglo XIII-XIV), apareciendo como vehículo de una narración extendida que también desplazará su contenido hacia los hechos de los últimos días de Jesús dando lugar a las representaciones de la Pasión en el siglo $\mathrm{XV}^{55}$.

En las ceremonias que se celebraban en Gandía según las descripciones citadas, la secuencia de su desarrollo define en efecto dos jornadas, como igualmente parece haberse hecho en las Descalzas: la que tenía lugar el Viernes Santo y la del Domingo de madrugada, de modo que son versión del antiguo ritual de la depositio y la elevatio, incorporando la escenificación del Quem quaeritis ${ }^{56}$. La ceremonia del viernes consistía, como hemos visto en el acta capitular gandiense, en la procesión del clero colegial que había de "ir a Santa Clara y pasar el Santísimo cuerpo de N. S. JesuCrísto del monumento mayor y encerrarlo en el otro, de donde se ha de sacar el día de la Santísima Resurrección", insistiendo al respecto en que el cabildo "haga hacer en Santa Clara el monumento pequeño, y pague el aceite que será menester y se quemará para iluminación del Santísimo Cuerpo de Jesu-Cristo, que allí estará encerrado hasta el día de la Resurrección", donde debían arder de continuo doce lámparas. La segunda jornada, en la madrugada del domingo, consistía en la procesión del clero y capilla musical "al monasterio de Santa Clara, y sacando el Cuerpo del Señor de dicho monumento, cantando himnos, y motetes, (...) lo llevase en procesión por las calles vecinas al monasterio, y al fin de ella, dejándolo encerrado en el trasagrario, se bolviese en la misma forma a la colegial"; en esta ceremonia se incluía la representación de la visita al sepulcro a la que corresponden los himnos y motetes cuyo ritual describe también Baixauli según "las anotaciones de los papeles de música" ${ }^{7}$.

Según esa consueta (que solo se refiere al domingo), la procesión se iniciaba con el canto Dum transisset Sabbatum, y al llegar a la puerta del monasterio comienza la re-

55 Cf. ibidem, y F. J. GRANDE QUEJIGO, "Huellas textuales en la documentación del teatro castellano medieval: el ciclo de la Pasión”, Anuario de Estudios Filológicos, XXV (2002), pp. 153-171, concretamente p. $154-155$.

56 GÓMEZ MUNTANÉ, op. cit. (nota 50); L. Quirante Santacruz, "La Visitatio Sepulchri de Gandía: consideraciones sobre su representación", en S. LA PARRA LÓPEZ et al., 'Visitatio sepulchri' de San Francesc de Borja, Gandía, CEIC Alfons el Vell, 1998, pp. 127-144; y VIVES RAMIRO, op. cit. (nota 50), quien realiza una reconstrucción para su recuperación en la Semana Santa gandiense actual que lo reduce a una jornada.

57 BAIXAULI, op. cit., (nota 47), p. 157-158. 
presentación dialogada entre dos cantores desde el interior, haciendo de ángeles, y la capilla musical desde el exterior en el papel (según parece, extendido) de las Marías (-Quem quaeritis in sepulchro, christicolae, -Iesum Nazarenum, o coelicolae, -Non est hic, surrexit sicut praedixerit, Ite nuntiate quia surrexit a mortuis, -Venite et videte locum ubi positus erat Dominus), momento en que se abren las puertas; ya en la iglesia se dirigen al monumento, que funciona como sepulcro, al que suben tres infantes vestidos de Marías con el canto Quis revolvit nobis lapidem ab ostio monumenti; allí, una por una, escenifican la acción con gestos de buscar, hasta que la tercera, María Magdalena, descubre la cortina que lo cubría y proclama Surrexit Christus, alleluia; repiten este canto bajando, para comenzar una segunda parte de la procesión en que se recorren las calles próximas al monasterio con los textos Victimae Pasqualis laudes y Dic nobis, Maria, quid vidisti in via.

Del traspaso a las Descalzas de Madrid de esa herencia tan apreciada de su casa madre da testimonio explícito la tan citada crónica de Llopis de 1781, quien afirma, como vimos, que "sólo se hace la misma ceremonia en el monasterio de las señoras Descalzas Reales de Madrid". También Baixauli lo afirma, aunque cabe pensar que siguiendo una vez más a Llopis y con información muy imprecisa: "en las Descalzas Reales de Madrid se celebra el Viernes Santo una procesión semejante a la que se celebraba en Gandía, en uso, sin duda del mismo privilegio (...), pero los responsorios que se cantan no son los mismos, ni en Gandía se cantaba canto figurado en dicha procesión. Con todo, el canto llano de Gandía guarda cierta semejanza con el de los versos que cantan los infantes en las Descalzas Reales" 58 . Sin embargo, tenemos noticia mucho más directa: es la referencia a la "procesión de sepultura que se dice con eu de las Marías" que consta entre las estipulaciones de los deberes de los capellanes de la notable capilla musical instituida por Juana de Austria al servicio de su monasterio ${ }^{59}$.

Sin embargo, la implantación en las Descalzas no fue un transposición literal, como por lo demás, según los especialistas, es habitual en la transmisión de estas ceremonias paralitúrgicas desde su origen. Aquí se adopta sin duda en una versión propia: por un lado, más recóndita puesto que no parece haber incluido procesión pública, de modo que se acomoda a un desarrollo conventual; por otro lado, más rica y elaborada, acorde a su regio patrocinio, que incluyó la realización de la estatua del Cristo yacente en función de arca del sacramento, que se traduce así a términos plásticos literales para su procesión. Y no solo eso, sino la construcción de la capilla ex profeso, de notable entidad artística, que materializa el escenario del sepulcro, ese espacio fundamental de la representación al que se dirigen las Marías preguntándose Quis revolvet nobis lapidem ab ostio monumenti? -como explícitamente queda representado y escrito en el interior de la capilla (vid. infra)-, para encontrarse con la otra pregunta esencial que les hace el angel, aunque aquí implícita: Quem quaeritis?.

Eso es lo más interesante y peculiar de esta capilla de las Descalzas de Madrid, que implica una teatralización muy signicativa en el modo de adaptar esa liturgia, literal-

58 BAIXAULI, op. cit., (nota 47), p. 283.

59 BNE, mss. 3843: Fundación de la Serenisima Prinçesa doña Joana del Real Convento de las Descalzas, copia de 8 abril de 1623, f. 44. 
mente dramatizada con su propio escenario físico. Pero, si el sentido de la capilla se identifica con claridad, más difícil resulta la reconstrucción de la liturgia y el ritual concretos configurados en el monasterio en su origen, a falta de documentación direc$\mathrm{ta}^{60}$. Hay que pensar que sin duda se representasen las dos jornadas y que en ambas tuviese un papel central la capilla del Cristo haciendo la función literal del sepulcro: su propia existencia implicaría su inclusión en el rito del viernes, cuando se deposita la hostia consagrada en el "monumento pequeño" - como se dice en Gandía-, simulación del sepulcro que contendrá el cuerpo de Cristo hasta la madrugada del domingo cuando resucite; y en este segundo momento, a la capilla debían acudir las Marías en esa madrugada para descubrir el sepulcro vacío y dar testimonio de la Resurrección. A ambos momentos se refieren las imágenes y textos en los muros de la capilla que detallaremos enseguida, aunque no recogen más que alguna de esas prosas, y sí otras, lo que indica también una elaboración más conceptualizada y rica en el diseño de su programa. Por lo demás, importante peculiaridad en las Descalzas hubo de ser la participación de la capilla musical del monasterio, como acabamos de señalar.

Volviendo a Tormo para finalizar este punto, en su estudio primerizo de 1912 sobre el Cristo yacente que citábamos al principio, solo da referencia sobre la forma de la procesión pública en el claustro de capellanes (al modo de la actual), ceremonia por completo diferente a las escenificaciones paralitúrgicas comentadas, aunque estas deben estar en su origen. Analiza la estatua llamando la atención sobre su composición para ser vista de un lado, dudando si su destino original fuera un retablo o ya como imagen procesional, tal como es sacado al caer la tarde de Viernes Santo, llevando el sacramento en el costado, de modo que funciona como imagen-custodia, según sus palabras ${ }^{61}$ : "Lo de menos en esa procesión son los profanos tapices de Rubens que cuelgan en el patio conventual. La música vieja, los niños tiples vestidos de monja, los cortos asistentes clérigos, vestidos los que ofician con terno negro espléndido, de bordada imaginería, (...) sobre todo la tradición, son circunstancias que hacen inolvidable, para quien una vez lo gozó, el Santo Entierro de las Descalzas: privilegiado por los Pontífices con el preciadísimo privilegio de no ser la imagen solamente una imagen, sino arca santa y santuario, a la vez que icona, pues se lleva en ella visible á

60 M. L. SÁNCHEZ, op. cit. (nota 41), p. 281-283, trae una descripción breve e imprecisa del ritual de las Descalzas sin dar referencia a fecha y sin correspondencia con la fuente que cita, que no lo contiene: Ejercicios de devoción y oración para todo el discurso del año del Real Monasterio de las Descalzas en Madrid, que mandó imprimir la Serenisima Señor Infanta Sor Margarita de la Cruz, Anvers, 1622. Las ceremonias que describe reproducen con leves variantes las de Gandía, con sus dos jornadas: el viernes, habiéndose colocado la hostia consagrada en la custodia del Cristo, se sacaba en procesión por el patio de clausura, iniciando el cortejo el "presidente de la asamblea" [sic] con tres tiples, entonando el Eu, eu, Domine y Eu, eu, Salvator noster, volviendo al altar de la capilla del Cristo donde se colocaba el Santísimo en el "monumentico" cantando el Sepulto domino; y la del domingo (que dice se celebraba el sábado muy de mañana), que sigue en textos y acciones el desarrollo de la Visitatio Sepulchri, si bien es confusa la localización del ritual, refiriéndose alternativamente a las puertas de la iglesia y de la capilla.

61 TORMO, op. cit. (nota 1), p. 66. Su encendido relato explica cómo en la mañana del viernes santo de 1912 pudo ver de cerca la imagen en la iglesia gracias a haberse permitido acceder a un grupo de estudiosos para ver los tapices de Rubens, concluyendo "que sólo como una opinión, basada en argumentos puramente subjetivos, pero con grande convicción personal, puedo ofrecer aquí, como obra de Gaspar Becerra, el siempre visto y nunca hasta ahora estudiado Cristo procesional de las Descalzas Reales de Madrid". 


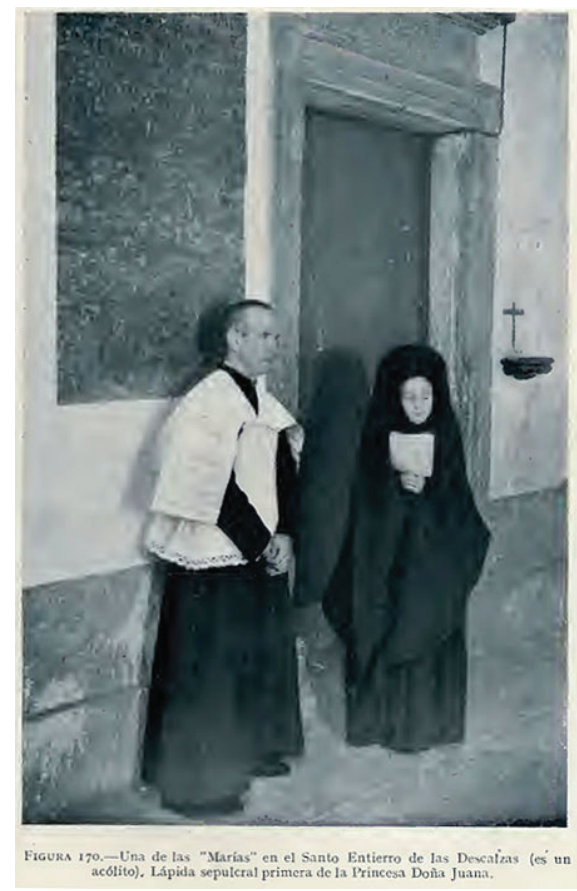

Fig. 5. Monasterio de las Descalzas Reales, Madrid. Fotografía reproducida en E. Tormo, En las Descalzas Reales. Estudios históricos, iconográficos y artísticos. IV, Madrid, Junta de Iconografía Nacional, 1947, fig. 170, con el siguiente pie: “Una de las 'Marías' en el Santo

Entierro de las Descalzas (es un acólito). Lápida sepulcral primera de la Princesa Doña Juana".

medias, dentro de la llaga del costado, en precioso relicario, á Cristo vivo, sacramentado, en presencia real en la Hostia consagrada. La «imagen-custodia» es llevada, por consecuencia, por sacerdotes, á hombros, como verdadero cadáver; no en caja, sino en parihuelas, sobre sábanas y envuelto en cendales sutiles, á través de las cuales se trasparentaba una cosa tremenda, cuyo mérito y aun cuya realidad de arte no podía ver el cristiano", insistiendo en el "el extraño privilegio de poner en la llaga del costado a Cristo Sacramentado, para así llevarlo en la procesión del Viernes Santo".

Poco después, en el primer volumen de sus estudios sobre las Descalzas Reales (1917), habiendo tenido noticia -aunque indirecta- del trabajo de Baixauli, ya relaciona ese privilegio como procedente de su monasterio madre de Gandía ${ }^{62}$. Finalmente, en el volumen cuarto del mismo libro (1947) da nuevamente noticia de la ceremonia procesional y añade un dato interesante: "En la tan corta, tan sencilla y tan emocionante procesión sólo claustral del Santo Entierro, a la tarde del viernes santo, secularmente se acompañan al yacente Jesús muerto las tres Marías: María

62 E. TORMO y MONZÓ, En las Descalzas Reales. Estudios históricos, iconográficos y artísticos. Madrid, Junta de Iconografía Nacional, 1917, p. 50 y p. 61. 
Salomé, María Cleofé y María Magdalena, las parientas de la Virgen María (...) las tres Marías no son imágenes, sino tres monaguillos cantores, que en momentos dados cantan música del siglo XVI, un motete que llevan en las manos. (...) Se le viste [a cada uno] (por sobre su ropa de calle) con una sola, amplia y cuadrada pieza de paño, que tradicionalmente se la saben plegar en forma que parece toda una indumentaria compleja; y sólo se le añade la aureola de santa a la cabeza, y en las manos, el papel de la música y la letra" ${ }^{63}$ (fig. 5).

\section{Pinturas, imágenes, textos y pintores}

Ateniéndonos a todo lo anterior, puede concluirse, como planteábamos al comienzo, que la capilla del Cristo fuese realizada en los primeros momentos de la instalación del monasterio en la casa del Tesorero de Madrid, hipótesis que no se contradice con las características morfológicas de la obra, como también advirtió Tormo en su brevísima mención a estas pinturas donde, en su apresurado recorrido por el monasterio, enumera las escenas con errores y principalmente para reafirmar su hipótesis sobre la fecha del Cristo y Becerra ${ }^{64}$.

La invención figurativa de la capilla responde a su concepción como trasunto del sepulcro de Cristo, incluyendo la imagen de su cadáver, pero al mismo tiempo, rodeado por los hechos de la Resurrección en el resto de imágenes, también como lugar de ese acontecimiento esencial que allí se produce. Y todo ello acompañado de un nutrido conjunto de textos que recogen referencias de diferente nivel a las palabras de la liturgia asociada a la representación del drama (fig. 6) (vid. también apéndice final).

Así, el interior está revestido por completo con pinturas murales que presentan un variado repertorio de elementos ornamentales, figurativos y epigráficos, y están ejecutadas íntegramente en grisalla aunque incorporando algunos detalles de pan de oro, lo que aporta al conjunto un tono solemne de suntuosidad contenida. La composición general se organiza en dos zonas bien delimitadas que se corresponden a muros y cubierta, según un sistema de quadratura simple con formas arquitectónicas sencillas abajo y motivos decorativos más abigarrados en la bóveda.

En los muros, como principal elemento regulador figura un orden de pilastras hasta el arranque de la bóveda; estos soportes debían levantarse seguramente sobre un zócalo o basamento simulado, ahora perdido, con el que también han desaparecido las presumibles basas de las pilastras. Tres de los paramentos -septentrional, meridional y oriental, que es el de acceso- muestran igual diseño arquitectónico, mientras el occidental, que hace de testero, es diferente; resultan más significativos los dos muros laterales al incorporar dos de las piezas figurativas importantes en el conjunto (fig. 7; fig. 8; fig. 9). En cada uno de los tres primeros se aparenta un frente tetrástilo con las pilastras de esquina dobladas, definiendo así una disposición tripartita con su sector

63 E. TORMO y MONZÓ, En las Descalzas Reales. Estudios históricos, iconográficos y artísticos. IV. Madrid, Junta de Iconografía Nacional, 1947, p. 107; añade que "el muchacho, acolitillo, de nuestro grabado, no cuenta sino once años, y se llama Hipólito de la Cruz".

64 TORMO, op. cit., 1917 (nota 62), p. 48. 


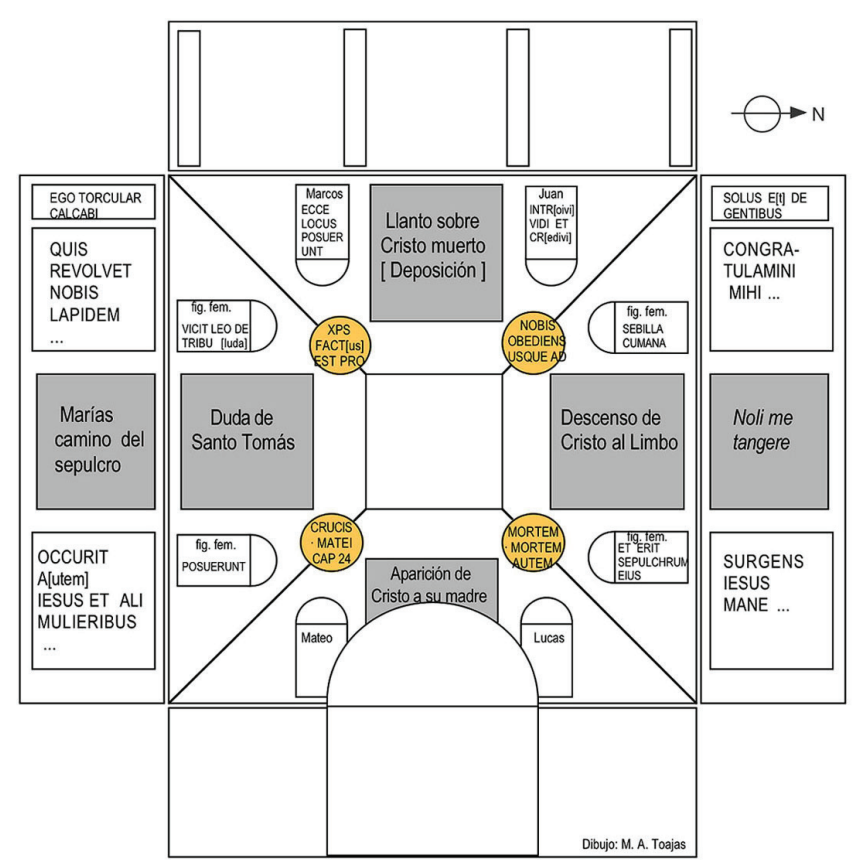

Fig. 6. Monasterio de las Descalzas Reales, Madrid. Capilla del Cristo: esquema gráfico de conjunto de las pinturas y epigrafías (dibujo M. A. Toajas).

central de doble anchura que los colaterales, que en el muro de ingreso se corresponde con la puerta. Este orden de pilastras muestra fustes lisos y capiteles clasicistas de un tipo corintio algo arcaizante; carece de entablamento, figurando soportar solo una doble platabanda representada sobre un listel -único elemento en relieve real-, que se corona con moldura dorada de ovas y dardos, y que marca el plano de impostas del abovedamiento. Las pilastras son la referencia para una articulación general de los muros, combinándose con otros elementos que simulan diferentes planos de profundidad.

Los dos paramentos laterales incorporan sendos quadri riportati que se figuran sobrepuestos a las pilastras centrales, ocultándolas parcialmente. Estos falsos cuadros son de gran tamaño, alcanzando su altura la totalidad del alzado arquitectónico, y van enmarcados en cercos de sencilla ornamentación, de superficie plana solo animada mediante cartuchos de fondo dorado dispuestos linealmente y, en los ángulos, con motivos de roleos vegetales en relieve aparente. Parte importante en el conjunto son los restantes intercolumnios, cuyos huecos se articulan fingiendo placas rectangulares en resalte, con sencillos cantos a bisel y superficies lisas dispuestas para contener inscripciones pintadas en grandes letras capitales negras; estos tableros se sitúan en dos registros, los superiores, apaisados, a la altura de los capiteles y los inferiores, verticales y mucho mayores, ocupando la dimensión de los fustes. La marcada pre- 


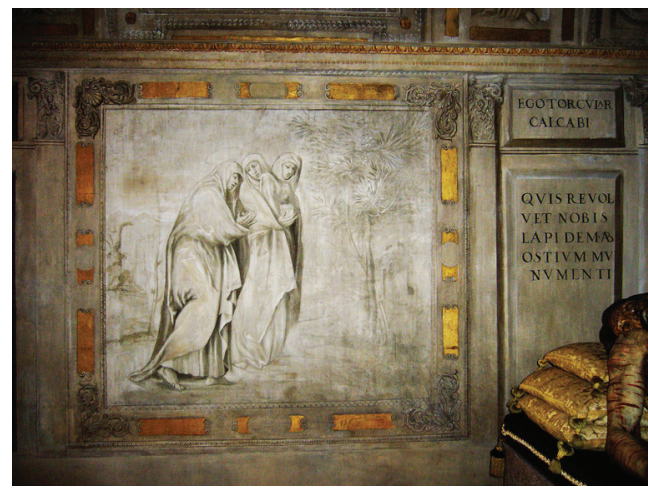

Fig. 7. Monasterio de las Descalzas Reales, Madrid. Capilla del Cristo: muro lateral izquierdo (sur), Las Marías camino del sepulcro.

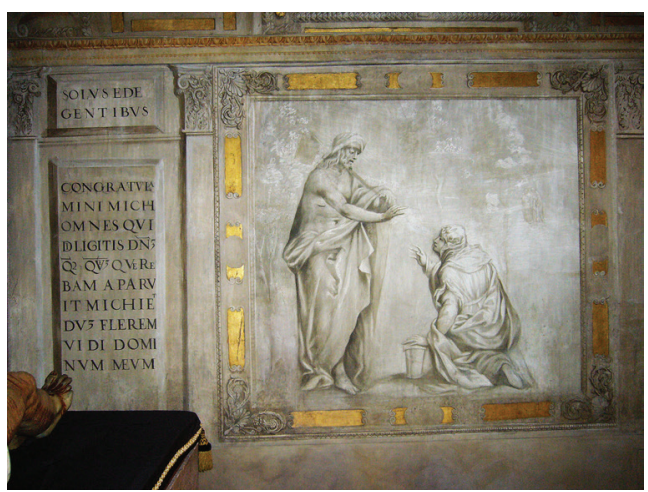

Fig. 8. Monasterio de las Descalzas Reales, Madrid. Capilla del Cristo: muro lateral derecho (norte), Noli me tangere.

sencia de tales placas epigráficas de voluminoso relieve evidencia que toda la composición depende de la intención de hacer presente la importancia de los textos en combinación con las imágenes (fig. 7; fig. 8).

En cuanto al muro testero, figura una arquitectura en perspectiva que pretende evocar un espacio secundario, concebido todo como un edículo para la escultura del yacente (fig. 9). Tiene en primer plano un frente adintelado con entablamento completo que apea sobre dos pilastras, y tras ello, abovedamiento simulando la profundidad de un espacio interior que se cierra al fondo con muro ciego articulado con dos pilastras iguales y placas lisas en los intercolumnios ${ }^{65}$. El orden arquitectónico representado aquí, mucho más severo, es toscano, con capiteles de faja de rosetas y friso pulvinado y ornamentado de característicos ochos dobles; este diseño resulta muy próximo a los alzados antiguos recogidos por Serlio (Libro IV, f. XXIv; Libro III, f. LXXVI), remitiendo también a modelos romanos muy usados entre los artistas del círculo de Rafael.

La bóveda, por su parte, muestra una composición más compleja y de mayor riqueza por la multiplicación de elementos figurativos y decorativos. La grisalla, salpicada de piezas de pan de oro, simula ricos moldurajes de estuco en superficie para enmarcar grandes escenas a modo de cuadros, pero también simula huecos en el muro, buscando un efecto de valor plástico (fig. 1; fig. 10 a 14). El diseño de conjunto es deudor de los tipos de bóvedas ornamentales italianas tan comunes en el segundo tercio del siglo a partir de los modelos romanos difundidos a través de Perino del

65 Este muro, y el paño de la bóveda sobre él, ha permanecido oculto largo tiempo, escondido tras de un altar-urna para el Cristo, un desabrido mueble probablemente del siglo XIX. La pintura actual es una reconstrucción a partir de los fragmentos originales conservados, realizada al ser retirada esa instalación (2005?); quedó entonces también a la vista la inscripción en el frente de la plataforma de fábrica que sirve de cama al yacente, un texto de las Horae Passionis Domini de San Buenaventura, según A. GARCÍA SANZ, "El monasterio de las Descalzas Reales: arte y espiritualidad en el Madrid de los Austrias", en Monasterio de las Descalzas Reales. Pinturas murales de la escalera principal, Madrid, Patrimonio Nacional-BBVA, 2010, p. 26. 


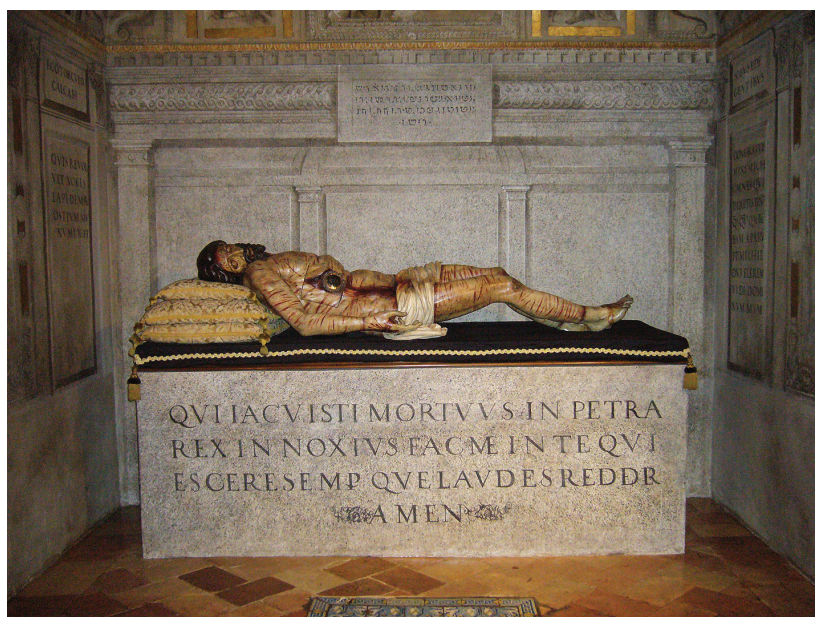

Fig. 9. Monasterio de las Descalzas Reales, Madrid. Capilla del Cristo: muro testero (oeste) y Cristo yacente.

Vaga y su círculo, que están presentes en la corte con Gaspar Becerra, que llega de Roma a Castilla en 1557 y está en Madrid desde 1562-63; muestra también cierta concomitancia con desarrollos de estos modelos en las decoraciones genovesas de mediados de siglo, que también vienen a la corte con Giovanni Battista Castello, el 'Bergamasco', llegado en 1564, aunque todo indica que es con el primero con el que hay que relacionar esta obra, como diremos.

La disposición general se organiza en base a los cinco paños de la estructura. En cada uno de los cuatro inferiores repite idéntico esquema, donde los elementos dominantes son cuatro grandes escenas que ocupan el centro del paño y van enmarcadas por esas molduraciones fingidas, quedando tangentes por sus vértices superiores; configuran una distribución en cruz, dejando al centro, en el plafón de la bóveda, un sector cuyo molduraje, a base de figuras geométricas inscritas una en otra, va rodeado por cuatro formas aveneradas y con un pequeño florón en el punto cenital de la bóveda (fig. 1; fig. 10). La composición se completa en las aristas con grandes tarjas rizadas en desarrollo vertical que contienen dos cartuchos ovales; delimitan así sectores triangulares en los paños a los lados del cuadro principal, donde se aparentan ocho hornacinas de medio punto para acoger un conjunto de otras tantas figuras, una en cada hueco; los frentes de estas pequeñas exedras van recuadrados sugiriendo placas recortadas que definen sus peanas, jambas y enjutas, y destacan sobre fondos dorados, con lo que resultan un recurso de gran efecto en el ornato general de la capilla (fig. 11).

Por lo que se refiere a los temas figurativos, aparecen dos grupos distintos: las seis escenas de contenido narrativo en los cuadros de muros y bóveda, que son dominantes, y ocho figuras representadas en las hornacinas de la bóveda. La narración, como ya hemos ido viendo, revela el tránsito de Cristo de la muerte a la resurrección, tomando como punto de partida el Llanto sobre Cristo muerto al pie de la cruz tras el 


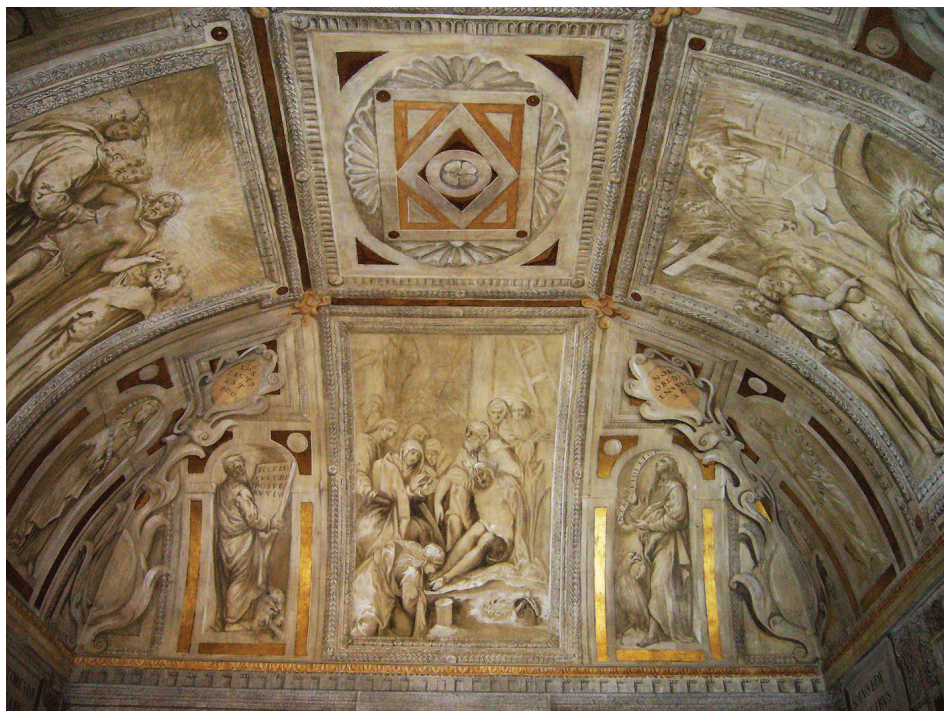

Fig. 10. Monasterio de las Descalzas Reales, Madrid. Capilla del Cristo: bóveda, vista general hacia el testero con el Llanto sobre el Cristo muerto, y figuras de San Marcos y San Juan.

descendimiento, escena que se representa en el paño de la bóveda frente al acceso de la capilla (fig. 10). Continúa con su entierro y sepulcro, materializados en la escultura del yacente y en la capilla misma; y el resto de escenas enumera los episodios inmediatos a su muerte y resurrección: los primeros hechos de Cristo resucitado según los textos de Marcos (cap. 16) y Juan (cap. 19 y 20), pero también dos hechos ajenos a los evangelios canónicos que aluden precisamente a los sucesos entre la crucifixión y la resurrección, esto es, su descenso al limbo y la aparición a su madre, que identifico en la escena perdida sobre la puerta como ahora se argumentará (fig. 7; fig. 8; fig. 12; fig. 13).

Por su parte, las ocho figuras individuales son los narradores, que llevan textos en tablillas y filacterias: están los cuatro evangelistas -paños oeste y este-, cuya identidad no ofrece duda, apropiadamente situados Marcos y Juan en lugar preferente según los episodios narrados (fig. 4; fig. 10); las otras cuatro figuras son femeninas y van sin atributos de identificación, pero una lleva escrito Sebilla Cumana en la filacteria que sostiene (fig. 13), de modo que en este contexto, según supongo, deberían ser cuatro sibilas (fig. 12; fig. 14). Sin que podamos entrar en esta cuestión, hay que recordar que su presencia en la iconografía cristiana como voces de la antigüedad pagana que previeron el advenimiento de un salvador, la Cumana en particular, es de larga tradición ${ }^{66}$, y aquí es coherente con los textos proféticos que llevan las otras,

66 La Sibila Cumana especialmente, como es sabido, se asocia a la profecía del salvador por la referencia a ella en la Égloga IV de Virgilio, donde la voz del poeta anuncia el inminente cumplimiento de la profecía de la Cumana sobre el nacimiento de un niño destinado a traer al mundo la paz y la abundancia de la mítica edad de oro. Su difusión se debe a las exégesis de Lactancio (Divinae Institutiones), Eusebio de Cesarea (Oratio 


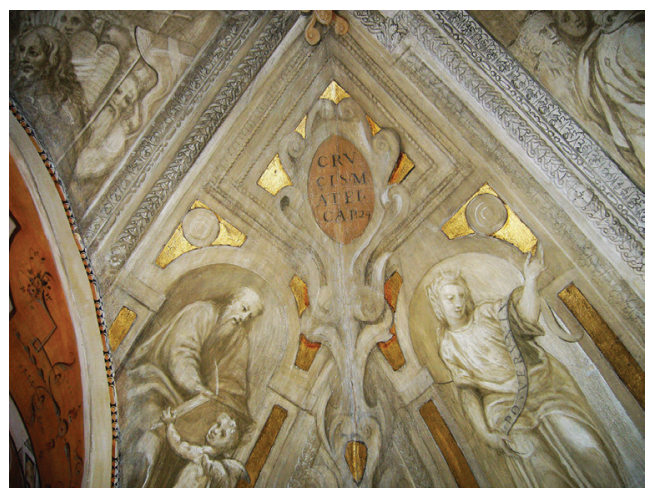

Fig. 11. Monasterio de las Descalzas Reales, Madrid. Capilla del Cristo: bóveda, detalle arista.

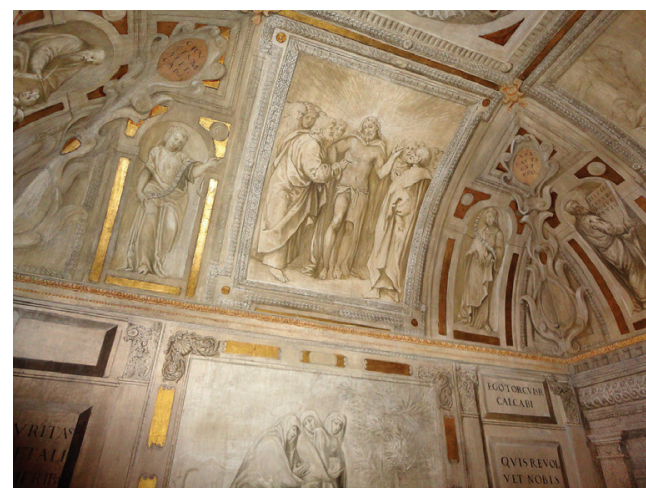

Fig. 12. Monasterio de las Descalzas Reales, Madrid. Capilla del Cristo: bóveda, paño meridional, Duda de Santo Tomás.

tomados del Apocalipsis e Isaías. Pero además, por lo que se refiere a este caso, la Sibila es interesante en cuanto que sugiere una novedad en la configuración del desarrollo habitual de esta paraliturgia, incorporando parte de la de Navidad, lo que podría explicarse a partir también de un modelo valenciano: como señala Donovan, la ceremonia paralitúrgica navideña en la catedral de Valencia fue de gran aparato y espectacularidad desde fines del siglo XV (una gran representación de los profetas con la Sibila), y precisamente el texto de esa dramatización dialogada aparece impreso en 1533 en una edición de las horas de la Semana Santa ${ }^{67}$, de modo que ese hecho podría justificar que se produjera esta asociación, que, por otra parte, desde el punto de vista del significado resulta coherente con la idea del Cristo vencedor de la muerte.

El conjunto de las pinturas, pues, ilustra los episodios que dan contenido a la celebración religiosa, reflejando sus dos momentos: el día de la muerte y sepultura, y la resurrección y los días de la Pascua; pero también recoge la voz de las escrituras representada en las figuras y en las palabras de sus testigos, que harían a su vez referencia a las voces de los oficiantes en la liturgia.

En cuanto a las escenas principales, en los muros se representan las dos secuencias relativas a María Magdalena, de acuerdo a su protagonismo en la paraliturgia descrita: Las Marías camino del sepulcro (Mar. 16:1-3) en el izquierdo (fig. 7) y la

Constantini ad Sanctorum Coetum) y San Agustín (De Civitate Dei), y de su presencia en las representaciones litúrgicas, la más significativa es el Cantus Sibyllae, monólogo dramático difundido en la Baja Edad Media, con origen de fecha incierta, que se refiere a la Sibila Eritrea y se asocia a las celebraciones de Navidad, $c f$. DONOVAN, op. cit. (nota 54), p. 165-167 (se remite a los estudios de referencia de S. Corbin). Sobre su representación plástica, $c f$. E. MÂLE, op. cit. (nota 53), y A. CHASTEL, Arte y Humanismo en Florencia en la época de Lorenzo el Magnifico, Madrid, Cátedra, 1982, p. 241-242.

67 DONOVAN, op. cit. (nota 54), p. 146: Hores de la Setmana Santa, ab una devotisima oració preparatoria per a tenir vera contrictio (...) E a la fin de dites hores, estan les matines de Nadal, ensemps a la missa del gall, Valencia, Francisco Romano, 1533; esos maitines de Navidad son una larga dramatización del pseudosermón de San Agustín sobre las profecías de la venida de Cristo, donde aparecen hasta dieciseis personajes -los profetas, y también Moisés, David, Nabucodonosor y Juan el Bautista- junto con la Sibila, que hace su canto al final en lengua vulgar. 


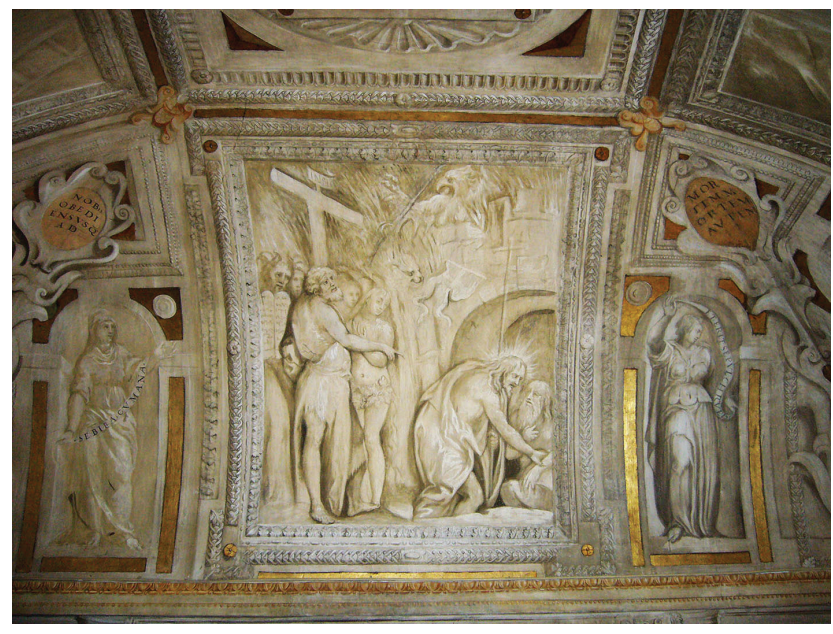

Fig. 13. Monasterio de las Descalzas Reales, Madrid. Capilla del Cristo: bóveda, paño septentrional, Descenso de Cristo al Limbo y figura de la Sibila Cumana (izquierda).

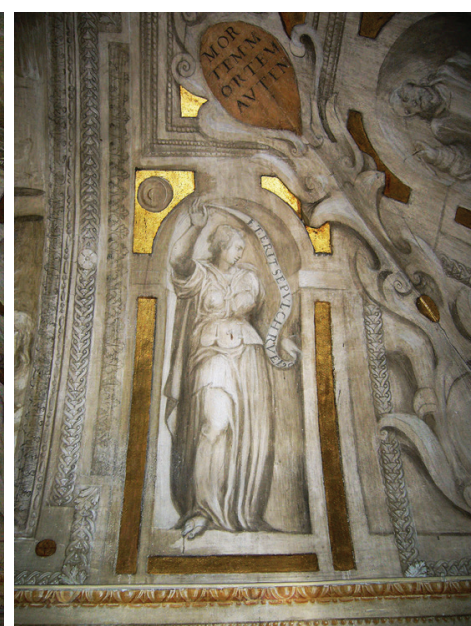

Fig. 14. Monasterio de las Descalzas Reales, Madrid. Capilla del Cristo: bóveda, paño septentrional, figura de una Sibila (derecha).

Aparición de Cristo a María Magdalena o Noli me tangere (Jn. 20:14-17, Mar. 16:9) en el derecho (fig. 8). En la bóveda, además de la lamentación sobre Cristo en el paño frontero, tema que en esta iconografía también alude a la deposición de la cruz (Jn. 19:38-39, Mar. 15:46), están la Duda de Santo Tomás (Jn. 20:26-29), a la izquierda (fig. 12), y el Descenso de Cristo al limbo, a la derecha (fig. 13). Sus iconografías ofrecen un interesante dato: todas ellas, salvo la primera escena -las Marías yendo al sepulcro-, copian las estampas de Durero sobre los mismos temas de la llamada $\mathrm{Pa}$ sión pequeña (1509-11) (fig. 15), reproduciéndolas casi literalmente, lo que aporta un interesante ejemplo que añadir a la casuística sobre la circulación de los repertorios durerianos en la España del siglo XVI, y en concreto entre los pintores de la corte ${ }^{68}$.

En cuanto al conjunto iconográfico-narrativo, hay que destacar el tema del descenso al limbo, que es significativo porque alude indudablemente a una parte de la paraliturgia que procede del antiguo rito de la elevatio, ceremonia en que se cantaba la antífona Tollite portas, principes, vestras et elevamini, portae aeternales, et introibit rex gloriae, que se refiere las del inframundo que Cristo franquea para rescatar a las almas cautivas. Como de nuevo Donovan advierte, un elemento interesante en la ceremonia de Gandía es el momento en que al llegar a las puertas del Monasterio se golpean con la secuencia Tollite portas, que constituye una dramatización escenificada del ritual antiguo; por otro lado, sugiere el modelo del Liber Sacerdotalis de

68 Ninguna de estas estampas se encuentra entre las catalogadas como de Durero que guardan las Descalzas de Madrid, que son siete de la Pasión grande, según L. RUIZ GÓMEZ, La colección de estampas devocionales de las Descalzas Reales de Madrid, Madrid, F.U.E., 1998, p. 153-154. Sobre la difusión de las estampas de Durero en los medios artísticos españoles del quinientos, $c f$. P. SILVA MAROTO, "Durero en España", en Durero. Obras maestras de la Albertina (catal. expos.), Madrid, Museo del Prado, 2005, pp. 41-76, p. 60-63. 

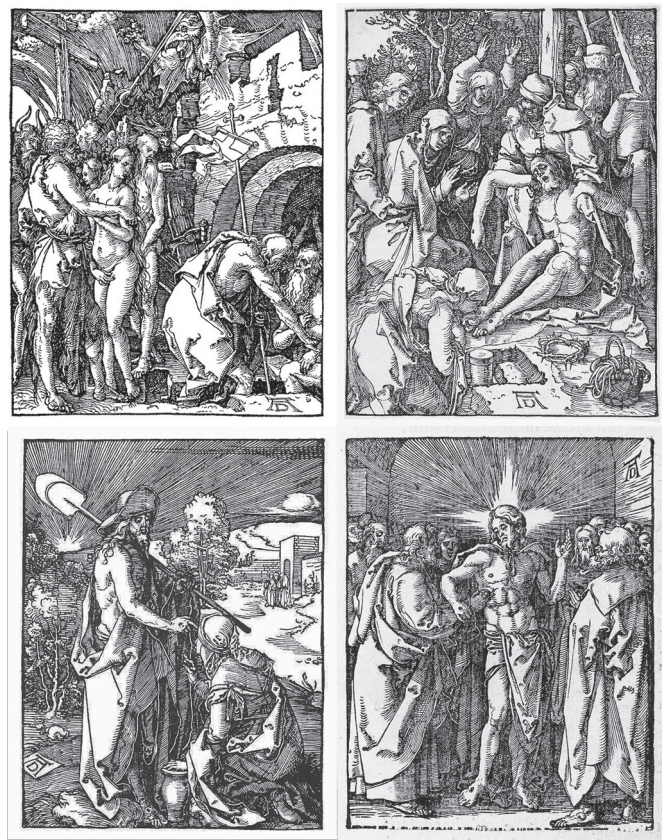

Fig. 15. A. Durero, Pasión pequeña, 1509-11: Descenso de Cristo al Limbo (n. 25); Llanto sobre Cristo muerto (n. 27); Aparición de Cristo a María Magdalena [Noli me tangere] (n. 31); Duda de Santo Tomás (n. 33).

A. Castellani (Venecia, 1523), donde, como remarcó Young, lo más destacable es la yuxtaposición de la fórmula Attolite portas con el diálogo Quem quaeritis ${ }^{69}$.

En el mismo sentido, es también importante la sexta escena, solo visible ahora en su parte superior, el fragmento superviviente de la modificación de la puerta de la capilla a que nos referimos arriba (fig. 4). A pesar de lo perdido, puede deducirse del diseño general de la bóveda y del fragmento mismo que debió tener el mismo tamaño y formato de las restantes; en lo que queda se ven los bustos de un grupo de personajes acompañando a Cristo resucitado, identificado sin duda por su nimbo radiante y el estandarte de la cruz, entre los que se distingue a Moisés con sus tablas y a David con su arpa. En este contexto, a mi juicio, debería ser la Aparición de Cristo a su madre, completando el ciclo de apariciones que aquí se ilustra. Este tema figura también en la misma serie de Durero, pero representado según un modelo iconográfico más arcaico que muestra a Cristo solo ante la Virgen; puede conjeturarse por tanto una utilización más libre de las estampas en este caso, o bien el uso de otro modelo, siguiendo una versión del tema extendida desde comienzos del siglo XVI -y precisamente en los reinos hispanos-, donde Cristo aparece ante su madre acompañado del cortejo de redimidos como en el descenso al limbo, versión que es de hecho resulta-

69 DONOVAN, op. cit. (nota 54), p. 142. Da por buena la autoría de Francisco de Borja sobre el ceremonial gandiense y señala este impreso veneciano como una referencia que el duque jesuita hubo de tener delante. 
do de una mixtificación iconográfica sobre ese mismo tema ${ }^{70}$. Por lo demás, ambos asuntos -descenso al limbo y aparición a María- proceden de textos narrativos sobre las escrituras difundidos desde fines del siglo XIV, especialmente la Vita Christi de Ludolfo de Sajonia, de amplia circulación en el XV y el XVI, y también por cierto en los medios ignacianos.

Así pues, la secuencia de escenas relata, según los evangelios canónicos, las apariciones de Cristo el día de la Resurrección y una semana después. Según Marcos, "Jesús, después de resucitado, al amanecer el primer día de la semana, se apareció primero a María Magdalena" (16:9), relato que se amplía en Juan que detalla cómo, ese día al descubrir el sepulcro abierto, se queda llorando junto a él y entonces ve aparecer a Jesús (20:14-17). También según Juan, aquel mismo día apareció ante los discípulos por la noche, sin estar presente Tomás, que lo dudó, y "ocho días después se hallaban los discípulos reunidos de nuevo en una casa, y esta vez también estaba Tomás", y aunque estaban las puertas cerradas, Jesús entró instándole a tocar sus 1lagas (20:26-27). Las otras dos escenas relatan dos hechos que no están en los evangelios, pero que las exégesis piadosas de raiz medieval sitúan en las horas que trancurren justamente entre la crucifixión y la resurrección: el descenso al limbo para redimir a los cautivos y la aparición a su madre, sugiriendo que esta aparición sería precisamente la primera.

El conjunto iconográfico de la capilla es coherente con los desarrollos más dramatizados de este tipo de paraliturgia, como analiza García de la Concha en su estudio citado $^{71}$. Basándose en las referencias que documenta señala la significativa incorporación de las apariciones de Cristo resucitado en este tipo de representaciones al menos desde el siglo XV. En concreto, en el Ceremonial Consuetudinario de la Iglesia de Palencia, dramatización litúrgica de gran aparato recogida en 1550 por el canónigo Arce (en gran parte copia de un Ordinario palentino del siglo XIV), se detalla cómo, tras descubrirse el sepulcro por dos niños vestidos de ángeles cantando Surrexit Domino, se va en procesión por el trascoro viejo recorriendo las capillas de Pasión, luego a un altar "en que está la Aparición de Cristo a su Madre", y desde allí al altar de la Cruz, remarcando así el camino de Cristo a la muerte y su retorno de ella.

Se remite asimismo a otro caso que por razón de fecha y localización ha de relacionarse aquí: la impresionante dramatización de la catedral de Braga que describe a mediados del siglo XVI el Missale Bracarense (Lyon, 1558), mandado imprimir en esa fecha por el arzobispo don frei Baltasar Limpo -aunque recogiendo una tradición anterior-. Siguiendo un ritual solemne y fastuoso, la ceremonia del viernes se escenifica con particular espectacularidad comenzando con el momento en que se toman

70 Cf. J. D. BRECKENRIDGE, "Et prima vidit: the iconography of the appearance of Christ to his Mother”, The Art Bulletin, 39 (1957), pp. 9-32, p. 28; señala el desarrollo a fines del siglo XV de estos episodios apócrifos que exaltan el papel de la Virgen en los hechos de la Pasión, y precisamente también el posible origen hispánico de este tema en que Cristo aparece a su madre con los redimidos del Limbo.

71 GARCÍA DE LA CONCHA, op. cit. (nota 54), p. 156-157. Diremos de paso que también estudia la que puede denominarse cuestión de los monumentos, asunto de frecuente confusión porque en las fuentes el término se refiere, a menudo sin más connotación que el contexto, a dos monumentos distintos, el de Jueves Santo y el la ceremonia del Viernes; eso, además del uso del término monumentum que, como es sabido, significa sepulcro (de donde la denominación de los litúrgicos). 
del altar las formas consagradas y, con el canto de la antífona Christus factus est, son colocadas en un féretro negro que, bajo palio negro y dorado, se lleva en procesión al sepulcro con los cantos Heu, heu, Domine! Heu, heu, Salvator noster! Es el tipo de ceremonia que justifica (como también apunta García de la Concha) las imágenes de Cristo yacente con teca eucarística, como sucede en las Descalzas.

Es precisamente el responsum de esa antífona el primer texto destacado entre el conjunto de los inscritos en la capilla ${ }^{72}$ (fig. 6). Sus palabras se reparten en continuidad en las grandes tarjas de las aristas de la bóveda, en sus cartuchos superiores adecuadamente destacados por su fondo en color dorado, comenzando en la izquierda sobre el testero: XPS FACT[u]S EST PRO /NOBIS OBEDIENS USQUE AD /MORTEM, MORTEM AUTEM /CRUCIS - MATEI 24 [Cristo se hizo por nosotros obediente hasta la muerte, y una muerte de cruz]. El texto procede de Pablo (Filip., 2:8), y por tanto, la mención a Mateo: 24, con que concluye la inscripción no ha de entenderse evidentemente como referencia de localización de la cita; esa referencia enlazaría, sin embargo, con los textos proféticos aludidos por las figuras femeninas debajo, porque ese capítulo se refiere al anuncio de Jesús sobre la destrucción del templo, el fin de los tiempos y el regreso del Hijo del Hombre.

El resto de los textos se distribuyen por la capilla en dos series de inscripciones, todas en letras capitales: en la bóveda, asociados a las figuras de las hornacinas, y en los muros, las más ostensibles por su gran tamaño, sobre las mencionadas placas destinadas precisamente a tal fin.

Comenzando por las primeras, los dos evangelistas en el paño frontero muestran lógicamente textos suyos propios (fig. 10). A la izquierda, Marcos, con su león, lleva una tablilla que dice ECCE LOCUS POSUERUNT, según su versículo 16:6; a la derecha, la de Juan, con su águila, lleva filacteria en que se ven fragmentadas las palabras INTR... VIDI ET CR..., que están seleccionadas de su versículo 20:8. Los otros evangelistas, Mateo y Lucas, están en el paño opuesto flanqueando el arco de acceso, con sus figuras recortadas por la modificación de la puerta y no llevan textos, quizá perdidos durante esa intervención.

En cuanto a las cuatro figuras femeninas de las hornacinas correspondientes en los paños izquierdo y derecho de la bóveda (fig. 12; fig. 13; fig. 14), todas sostienen filacterias con inscripciones referentes a otros textos bíblicos, según parece alusivos a la venida del Salvador que triunfará sobre la muerte. Siguiendo de izquierda a derecha, la primera dice POSUERUNT, verbo que, en este contexto, debe suponerse epítome del entierro de Cristo y que se repite en los principales versículos de Marcos y Juan referidos sepulcro (además del citado arriba: Mar. 6:29, Ju. 19:42 y 20:13). La segunda dice VICIT LEO DE TRIBU, del Apocalipsis, 5:5. En el lado derecho, frente a esta última aparece la figura que lleva la leyenda SEBILLA CUMANA y en la última se lee ET ERIT SEPULCHRUM EIUS, que procede de Isaías 11:10. La aparente identificación de esa sibila cumana induce a suponer, como decíamos, que lo sean las cuatro en su papel de an-

72 Vid. infra Apéndice, donde se enumeran todas las inscripciones según su ubicación en la capilla y sus fuentes, que cito por la Biblia Vulgata Clementina (1592). Quiero agradecer también aquí a mi amigo Miguel Martín Echarri, doctor en filología hispánica y músico, su inestimable ayuda en la consulta del Index of Gregorian Chant. 
cestrales profetisas de la venida de un salvador victorioso, a lo que hacen referencia también los textos del Apocalipsis y de Isaías de las otras dos.

Mucho más visibles son las epigrafías en los dos muros laterales, sobre los tableros a ambos lados de los cuadros centrales. En los pequeños, situados a la altura de los capiteles, aparece una única inscripción que enlaza las dos del fondo leyéndose del izquierdo al derecho: EGO TORCULAR CALCABI [sic] /SOLUS ET DE GENTIBUS; el texto procede de Isaías 63:3, difundido a través de los comentarios de San Agustín, que forma parte del recitado de los Improperia en los oficios de Semana Santa; por otra parte, su interpretación alusiva a la sangre vertida por Cristo es fundamento también del tema iconográfico medieval del Torculus Christi, donde Cristo aparece en un lagar asociando las uvas pisadas con su sangre.

En las grandes placas inferiores del lado izquierdo se leen dos fragmentos de Marcos y Mateo que flanquean apropiadamente la escena de las Marías caminando hacia el sepulcro: QUIS REVOLVET NOBIS LAPIDEM AB OSTIUM MONUMENTI (Mar. 16:3); y OCCURIT A[utem] IESUS ET ALI MULIERIB[us] DICENS AVETE ILLE AUT[em] ACCESERUNT ET TENUERUNT PEDES EIUS ET ADORAVERUNT EUM (Mat. 26:9). Estas frases forman parte de los textos comunes en la Visitatio Sepulchri, repetidos en diferentes versiones documentadas de esta dramatización; el primero está también en la versión de Gandía.

En las del lado derecho los textos aluden específicamente a María Magdalena, acompañando la escena del Noli me tangere. La inscripción más próxima a la puerta dice: SURGENS IESUS MANE PRIMA SABBATI APARVIT PRIMO MARIAE MAGDALENAE STABAT AD MONUMENTUM FORIS PLORANS, combinando, aunque sin respetar el orden narrativo, dos textos de los relatos de Marcos y Juan en que se habla de su llanto ante el sepulcro y de esa primera aparición de Jesús resucitado precisamente a ella (Mar. 16:9, Juan, 20:11). La primera frase es una antífona que, combinada con la segunda, aparece asimismo en varias dramatizaciones pascuales, como la bracarense citada.

Finalmente, el segundo texto del muro derecho recoge asimismo el motete conGRATULAMINI MIHI OMNES QUI DILIGITIS DOMINUM, QUIA QUEM QUAEREBAM APPARUIT MIHI: ET DUM FLEREM AD MONUMENTUM, VIDI DOMINUM MEUM. El texto no es bíblico, sino un desarrollo dramático parafraseando las escrituras y los textos relativos a la Magdalena en el sepulcro, junto a la fórmula de júbilo de sus palabras iniciales (está en los episodios de la oveja perdida y el dracma perdido, Lucas, 15:6 y 15:9). Esta prosa es muy repetida en la música del siglo XVI para la Pascua de Resurrección y se conocen composiciones destacadas de T. Crecquillon (1505 ca.-1557) y G. P. Palestrina (1525?-1594). Pero también, mucho más próximo a las Descalzas, fue utilizada por Francisco Guerrero (1528-1599) en una misa parodia del motete de Guillaume Le Heurteur, que publica en su Liber primus Missarum (París, 1566) ${ }^{73}$; dedicó esta edición al rey Sebastián de Portugal, para lo que viajó expresamente a Lisboa en enero de ese año con carta de recomendación expresa de su madre, la Princesa Juana ${ }^{74}$. Así pues, aunque Guerrero vivió y trabajó siempre en la catedral de su Sevilla natal, están bien documentados sus viajes y difundió ampliamente su obra en diferentes edicio-

73 J. M. LLORENS, Francisco Guerrero. Opera Omnia. VII, Barcelona, C.S.I.C., 1991, p. 42-43.

74 J. MOLL, "La Princesa Juana de Austria y la música. Notas para su estudio", Anuario Musical, 19 (1964), pp. 119-122: AHN, Consejos, Lib. 1432. 
nes, y datos como el indicado hacen muy plausible la contribución de Guerrero a la música en las Descalzas. En cuanto a Tomás Luis de Victoria, que también lo utilizó, su presencia en el Monasterio es muy posterior, después de 1586, cuando a su regreso de Roma entra al servicio de la Emperatriz María.

En fin, este abundante conjunto epigráfico reproduce partes significativas de los responsorios asociados a la liturgia de las ceremonias comentadas. Cabe añadir que, a falta de documentación detallada sobre la forma de ese ceremonial en las Descalzas, parece que aquí, a partir de la dramatización litúrgica de Gandía, se elaboró una adaptación más solemne y enriquecida, sin duda en el sentido artístico, pero también seguramente en el ritual; la interpretación parece más conceptual, donde la representación se materializa en la construcción del escenario, que es la propia capilla, y en la narración de las pinturas, pero donde también se inserta un epítome de la liturgia. Al mismo tiempo, para esta configuración del drama paralitúrgico hay que pensar en su dependencia también de los impresos citados: el veneciano de Castellani, de 1523, el valenciano de 1533 y, por coincidencia de fechas y elementos de la representación escénica, pero también por la vinculación portuguesa de Juana de Austria y Francisco de Borja, el Missale Bracarense de 1558. Eso, además de la incorporación de prosas y músicas en la capilla real de la Princesa, que acabamos de señalar.

Por lo que se refiere a la ejecución de las pinturas, lo más evidente es su dependencia de modelos italianos en cuanto a la concepción general de la estructura decorativa y sus detalles, como ya se apuntó. En cuanto a la factura destaca la diferencia de tratamiento entre las partes del conjunto: detallada y atenta en los elementos decorativos y casi abocetada en los figurativos, en algunos puntos meramente esbozados. El resultado es el énfasis en el efecto plástico de los estucos fingidos, mientras que las escenas están tratadas como pinturas monocromas y no como relieves, y tampoco las figuras de las hornacinas están apuradamente resueltas en su representación como esculturas; y por otro lado, se observan diferencias estrictamente figurativas que indican varias manos. Puede pensarse en cierto apresuramiento en la ejecución, pero también hay que considerar las características y función del sitio, un lugar recóndito y oscuro, seguramente ni siquiera muy visible en los días de las funciones litúrgicas dichas; en ese sentido es de gran eficacia el tratamiento de la bóveda, abigarrada y con oro, para ser vista a la luz de hachones.

El diseño, por su parte, responde a los modos italianos que se implantan en las obras reales de Madrid y su entorno justamente en la década de 1560. Responde también a la preferencia por parte de la Princesa por ese lenguaje, o por el prestigio de los artistas que llegan de Italia al servicio del rey, de lo que da buena cuenta el proyecto de la iglesia que construye, como hemos argumentado otras veces. Desaparecido lo realizado en aquellas obras regias en estas fechas, no hay elementos para un estudio comparativo, salvo el techo de la torre de la reina de El Pardo, cuya concepción decorativa y composición no está ajena a esta, teniendo en cuenta el carácter tan distinto de las dos obras y la particular función que venimos comentando sobre la capilla.

Así pues, de acuerdo a nuestros argumentos respecto a las fechas, resulta lo más plausible que el proyecto se deba en efecto a la ideación de Becerra, cuya autoría de los retablos de la iglesia de la Princesa es afirmada en 1568 por Juan López de Hoyos, 
que vio la iglesia en los días de su inauguración, y también confirmada por testimonio del embajador de Portugal el 3 de febrero de 1568: "[el mejor oficial es el] que pinto el retablo del monasterio de la Princesa nuestra señora, llamado Bezerra, que murio hara diez o doce dias"75. Hay que recordar también la temprana relación de Becerra con el entorno de la corte de la Princesa en Valladolid, adonde se dirige a su regreso de Roma en 1557 seguramente en razón de la estancia de la corte allí, como se ha documentado y argumentado ${ }^{76}$. Por tanto, a mi juicio, la ejecución del conjunto de la capilla del Cristo debe entenderse como obra de taller, siguiendo proyecto y directrices de Becerra, obra que habría abordado al instalarse en Madrid en 1562-63, en el momento en que está en construcción la iglesia y se hacen las obras de adaptación del nuevo monasterio, y cuando se le encargaría también el famoso retablo. Por lo demás, ello abundaría en la propuesta de Tormo respecto al Cristo yacente, que él basa en su análisis formal.

En este sentido, creo de interés aportar dos noticias procedentes del finiquito de la testamentaría de Juana de Austria, donde se documentan pagos a Diego de Urbina y Juan de Cerecedo por trabajos de pintura que ambos habían realizado para la Princesa; constan en la escritura pública otorgada por sus testamentarios en Madrid el 22 de octubre de $1574^{77}$ :

75 Apud F. BOUZA, Imagen y propaganda. Capítulos de historia cultural del reinado de Felipe II. Madrid, Akal, 1998, p. 23: Francisco Pereira a Catalina de Austria (Arquivo Nacional Torre do Tombo, Conselho Geral do Santo Officio, livro 105): "Quanto ao pintor que me vossa Alteza manda lhe busque (...) aquy esta hum que chamâo Urbino que he o melhor official que ha nesta terra, tirando o que pintou o rretavulo do mosteiro da Princesa nossa senhora que chamabâo Bezerra, que morreo avera dez ou doze dias"; la mención a este Urbino bien pudiera ser Diego de Urbina (vid. a continuación), porque Francesco da Urbino, el genovés venido a requerimiento del Bergamasco para la decoración del Alcázar, llegó a Madrid en 1569 (P. CAROFANO, "Francesco da Urbino y la decoración de la celda baja del prior", en M. di GIAMPAOLO (coord.), Los frescos italianos de El Escorial, Madrid, Electa, 1993, pp. 99-104, p. 99).

76 F. J. SÁNCHEZ CANTÓN, "Los pintores de cámara de los reyes de España", BSEE, XXII (1914), pp. $62-80$ y $133-160$, p. 153, ya sugirió que Becerra lograse en Valladolid el patrocinio de Juana. Sobre Becerra, su trayectoria italiana y su regreso a Castilla, $c f$. C. FRACCHIA, "La herencia italiana de Gaspar Becerra en el retablo mayor de la catedral de Astorga", Anuario del Departamento de Historia y Teoría del Arte UAM, IX-X (1997-98), pp. 133-151; M. ARIAS MARTÍNEZ, "Gaspar Becerra, escultor o tracista. La documentación testamentaria de su viuda, Paula Velázquez", AEA, 283 (1998), pp. 273-288; G. REDÍN MICHAUS, "Sobre Gaspar Becerra en Roma. La capilla de Constantino del Castillo en Santiago de los Españoles", AEA, 298 (2002), 129-144; ID., Pedro Rubiales, Gaspar Becerra y los pintores españoles en Roma, 1527-1600, Madrid, C.S.I.C., 2007; y F. J. HERRERA GARCÍA, "Gaspar Becerra: su entorno familiar y profesional a la luz de nuevas fuentes documentales", Boletín del Mus. e Inst. Camón Aznar, XCIII (2004), pp. 59-95.

77 AHPM, Prot. 458, Francisco Ortiz, f. 830-862v: Carta de pago y finiquito de los testamentarios de Juana de Austria: fray Juan de Vega, su confesor; Rodrigo de Mendoza, su Mayordomo; Cristóbal de Mora, su Caballerizo Mayor; Diego de Arriaga, su Secretario; y Antonio Cordero, su Guardajoyas. Madrid, 22 octubre 1574 (con traslados de 30 septiembre 1573). Documento ya publicado en TOAJAS, op. cit., 2014 (nota 4), p. 72, ahí para la noticia de una primera traza para el retablo de la iglesia realizada por Giralte; contiene también varios pagos a joyeros y plateros, tanto para piezas de ajuar personal de la Princesa como para donaciones de ajuar litúrgico, destacando el siguiente: “A Alonso Muñoz, platero, $375.000 \mathrm{mrs}$, que los hobo de aver por çiertas cosas que, por horden de los dhos señores testamentarios, hizo en cumplimiento de lo que por Su Alteza dexo mandado por una clausula de su testamento, como paresçe por menudo por una çertificaçion de Antonio Guerrero y Antonio Cordero que esta a las espaldas de la librança de los dhos señores testamentarios, fecha a 26 de hebrero de 1574 años, los quales resçivio el mismo. Esta partida es la de los caliçes”, f. 842r. 
"A Jhoan de Cerecedo, pintor, doçientos noventa y un mill y quatrocientos y quarenta y seis mrs que se le restaron debiendo por las pinturas en un memorial contenidas, que las hizo por orden y mandado de Su Alteza, por çedula de los dhos señores testamentarios, fecha el dho dia [23 diciembre 1573], los quales resçivio el mismo" (f. $847 \mathrm{v}$ );

"A Diego de Urbina, pintor, treçientos reales que valen diez mill y dosçientos mrs, que se le mandaron pagar por las traças y dibuxos y pinturas que hizo por mandado de Su Alteça para cosas de su serviçio, por çedula de los dhos señores testamentarios, fecha a primero de abril del dho de quinientos y setenta y quatro, los quales resçivio el mismo" (f. 859v).

Estos datos no permiten evidentemente establecer relación inequívoca con esta obra concreta, ni atendiendo a las cantidades abonadas, que son liquidación de montos mayores como expresamente se dice en el caso de Cerecedo, ni a las fechas, que se refieren a las de los pagos por los albaceas; no obstante, sí documentan el trabajo de estos pintores al servicio de Juana de Austria y creo que indudablemente en el edificio de las Descalzas, sin que se pueda descartar esta capilla ${ }^{78}$.

Por lo demás, respecto a Cerecedo es noticia que añadir a las escasas conocidas ${ }^{79}$. Y en el caso de Diego de Urbina, aunque en estas pinturas es difícil reconocer estilo, podrían relacionarse con obras suyas y especialmente con las sargas en grisalla que realiza a partir de 1563, cuando Becerra, llegado a Madrid pocos meses antes, le traspasa el encargo de las de los Jerónimos de Madrid "por estar ocupado en El Pardo en serbiçio de Su Magestat", tras las cuales se documentan también las que hace entre 1568 y 1570 con el retablo del Monasterio de Santa Cruz de Segovia, todo por donación de Felipe II $^{80}$. La relación entre los dos pintores, que arranca desde el primer momento de la llegada de Becerra, se mantendrá hasta la muerte del andaluz en 1568 y ese mismo año Urbina y su hermano Francisco de Ampuero actúan como testigos del testamento de su viuda, Paula Velázquez ${ }^{81}$. Todo ello da cuenta en cualquier caso de la actividad de este grupo de pintores en la corte y, por lo que a Gaspar Becerra

78 M. R. ZARCO DEL VALLE, Documentos inéditos para la historia de las bellas artes en España, CODOIN, t. LV, Madrid, 1870, p. 386-387, a pie de página da la siguiente noticia: "Los originales de este documento y el que le sigue, con otros papeles relativos a la fundación de aquel convento [de las Descalzas], donde aparecen (en 1574) detalladas las obras del pintor Juan de Cerecedo, y los nombres de los tasadores Diego de Urbina y Cristiano de Amberes, me fueron regalados en 1866 por mi buen amigo el erudito D. Cayetano Alberto de la Barrera". Creo que la tasación debe referirse a este mismo proceso de finiquito testamentario.

79 Ceán le identificó como pintor vecino de Alcalá, en 1577 tasador a favor de Sanchez Coello en el retetablo de El Espinar (Diccionario histórico de los más ilustres profesores de las Bellas Artes en España, Madrid, 1800, t. I, p. 311). Aportaciones recientes en R. GONZÁLEZ RAMOs, "La visita del archiduque cardenal Alberto de Austria a la Universidad de Alcalá de Henares y la obra efímero-emblemática del pintor Juan de Cerecedo", Boletín del Museo e Instituto Camón Aznar, 90 (2003), pp. 77-98, y "Para una cronología del pintor Juan de Cerecedo", Boletín del Museo e Instituto Camón Aznar, 99 (2007), pp. 167-198.

80 T. DE ANTONIO, "Dos sargas de Diego de Urbina depositadas en el Parral de Segovia", Boletín del Museo del Prado, 32 (1993), pp. 33-40, p. 34 y 37. Cf. también, EAD., Pintura española del último tercio del siglo XVI: Navarrete, Carvajal y Urbina, Madrid, Universidad Complutense, 1987, y F. COLLAR DE CÁCERES, "Diego de Urbina (1516-1595). Pintura y mecenazgo antes de 1570", Anuario del Departamento de Historia y Teoría del Arte UAM, XXII (2010), pp. 103-136. Para el trabajo de Urbina en la capilla funeraria de Alonso Gutiérrez y María de Pisa, TOAJAS, op. cit, 2005 (nota 5), p. 102-103 y 109-111.

81 ARIAS MARTÍNEZ, op. cit. (nota 76), p. 279. 


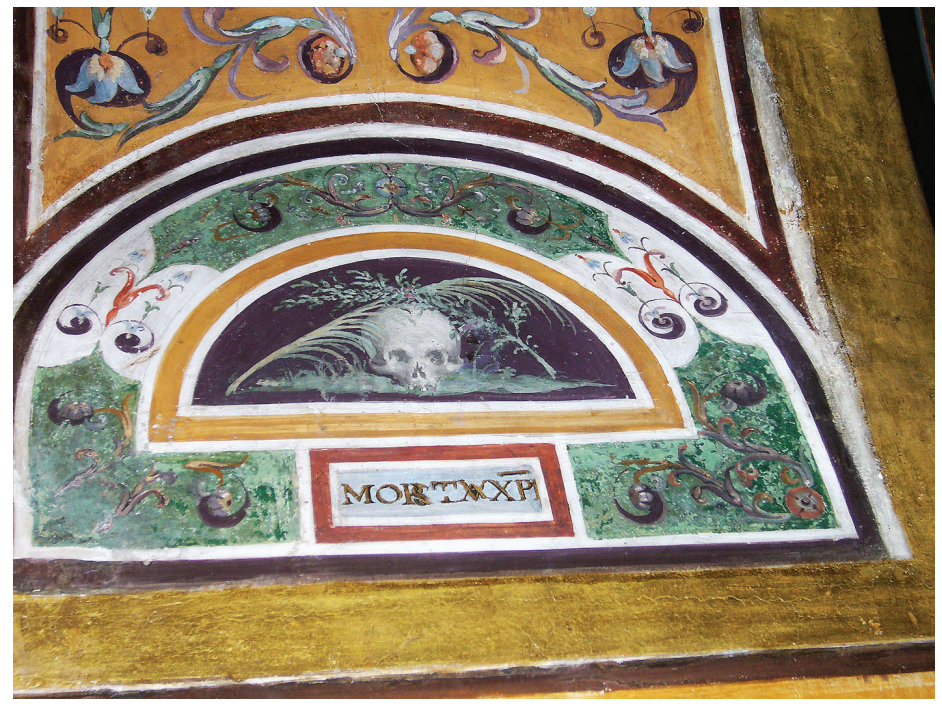

Fig. 16. Monasterio de las Descalzas Reales, Madrid. Capilla del Cristo: pintura en el intradós del arco de acceso sobre la imposta derecha.

se refiere, el papel que le supongo aquí también se ajusta a su modo de trabajo como inventor de diseños y cabeza rectora de ejecuciones colectivas, tal como había aprendido en Roma (en medios de muy superior calidad artística, ciertamente).

Haremos mención por fin a las pinturas del exterior de la capilla, que forman una suerte de portada arquitectónica, y también a la modificación ya señalada en el vano de acceso, obras que de uno u otro modo hay que relacionar entre sí. En cuanto a esta última obra, que consistió en la ampliación de la puerta -sobre todo en altura- ocasionando el recorte de las pinturas de la bóveda que se ha visto, puede creerse de los últimos años del siglo. La apertura del arco perforando la bóveda generó un profundo intradós que se pintó con policromía y técnica distintas a lo precedente (fig. 4). Muestra una decoración sencilla de motivos vegetales estilizados derivados del grutesco, que remite a los repertorios ornamentales de El Escorial hacia 1585-90 (N. Granello, F. Castello), pero también incluye en lo alto la imagen de un corazón con tres clavos, y abajo, sobre las impostas, dos tarjetones en medio punto con fondo negro -uno de ellos con una calavera (fig. 16)-, y entre ambos la inscripción "Mors TUA XRISTI / VITA NOSTRA", todo lo cual conduce al repertorio emblemático de los jesuitas y quizá a una fecha más próxima a $1600^{82}$.

En cuanto a la portada exterior, la pintura -aunque maltrecha y parcialmente perdida- permite ver su diseño, muy italiano, simulando estucos blancos que forman dos pilastrones muy articulados, integrando piedras ricas polícromas y todo ribeteado

82 Vid. J. GÁLlEGO, Visión y símbolos en la pintura española del Siglo de Oro, Madrid, Aguilar, 1972 , p. 103: señala como primer ejemplo del emblema del corazón con los tres clavos hincados el que aparece en el blasón de la Compañía en el frontispicio del libro del jesuita J. DE PINEDA, Commentariorum in Job Libri Tredecim, Sevilla, 1598. 


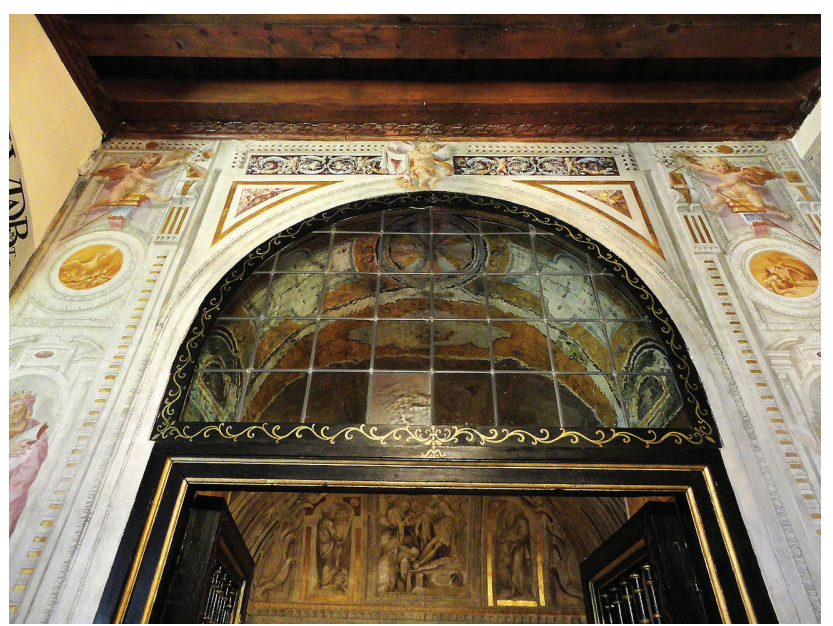

Fig. 17. Monasterio de las Descalzas Reales, Madrid. Capilla del Cristo: portada, detalle.

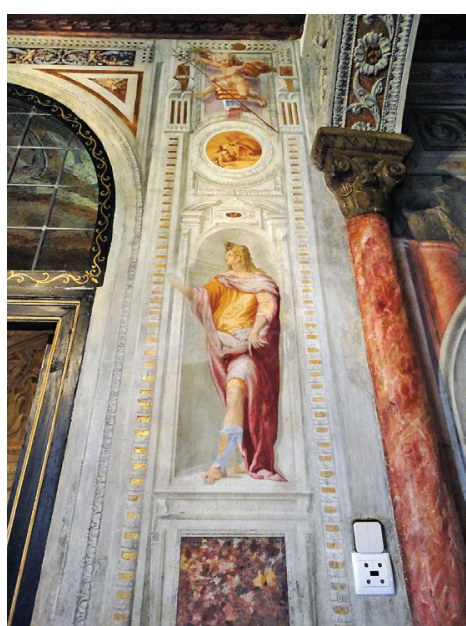

Fig. 18. Monasterio de las Descalzas Reales, Madrid. Capilla del Cristo: portada, jamba derecha.

de molduras ornamentales con detalles en oro. La estructura representada tiene altos basamentos con grandes volutas verticales, y encima, sendas hornacinas coronadas por frontón partido en doble S donde se alojan dos figuras identificadas con sus nombres: David, a la izquierda, y Daniel, a la derecha; más arriba, dos tondos que simulan relieves en bronce con episodios relativos; el remate superior se resuelve en cada lado en forma de seudo capiteles-triglifo, donde se acomodan una pareja de angelitos, y enlazando ambos lados por encima de la clave del arco va un friso de roleos vegetales de tonos más intensos que el resto (fig. 17; fig. 18).

Las pinturas son de calidad notable y gran cuidado en la factura, sobre todo en la zona del cuerpo central; según los rasgos morfológicos de la arquitectura y las figuras, responden sin duda a un diseño diferente al del interior de la capilla, también en su concepto de escala y ejecución, y deben ser posteriores; digamos también, por otra parte, que esta portada debe formar conjunto con otras tres portadas de pintura, peor conservadas que ella, que se ubican en las otras tres esquinas del claustro alto, que parecen de similar hechura, aunque con variantes compositivas más esquemáticas, hasta donde su estado permite entender. Las figuras de Daniel y David podrían recordar el estilo de algunas de las de Cincinato en el coro de El Escorial y en detalles de los altares del claustro grande, por lo que cabría pensar en este taller y en esos primeros años en que, muerto Becerra en enero de 1568, está en Madrid al menos en 1569 y pintando en el Alcázar en $1572^{83}$. De ser esta portadita anterior a la modificación del acceso de la capilla, la parte superior habría sido evidentemente rehecha al

83 A. ZEZZA, "Romolo Cincinnato: los frescos del coro y del claustro de los Evangelistas", en M. di GIAMPAOLO (coord.), Los frescos italianos de El Escorial, Madrid, Electa, 1993, pp. 121-124. 
peraltarse la puerta, como así parece, porque la pareja de angelitos, que es calco de los que hay en El Escorial en los testeros de las salas vicarial y prioral, aparenta ser de otra factura. Así pues, la cuestión es si al agrandar el vano se arreglase la parte alta de la pintura existente, o si todo el conjunto se hubiese realizado entonces, es decir, alrededor de 1590.

En cualquier caso, esa intervención en la puerta de la capilla indica otras necesidades y usos a fin de siglo, quizá un ceremonial más ampuloso en la liturgia del Cristo. Esta obra formaría parte de las realizadas en tiempos de la Emperatriz María de Austria, la hermana mayor de Juana, que se instala en el cuarto real de las Descalzas en 1581 y allí vivirá hasta su muerte en 1603; y con ella, como indican los emblemas pintados en ese arreglo, se abre una nueva etapa en la historia de esta casa que ya no abordaremos aquí.

\section{Siglas utilizadas}

AGS - Archivo General de Simancas

AHPM - Archivo Histórico de Protocolos de Madrid

AP - Archivo del Palacio Real de Madrid

BNE - Biblioteca Nacional de España

RAH - Real Academia de la Historia, Madrid

AEA - Archivo Español de Arte

AHSI - Archivum Historicum Societate Iesu

BRAH - Boletín de la Real Academia de la Historia

BSEE - Boletín de la Sociedad Española de Excursiones

CODOIN - Colección de documentos inéditos para la historia de España

MHSI - Monumenta Historica Societatis Iesu

\section{Apéndice: relación de textos en las epigrafías de la capilla y sus fuentes}

En la bóveda:

1) Cartuchos de las tarjas en las aristas:

XPS FACT[u]S EST PRO /NOBIS OBEDIENS USQUE AD /MORTEM, MORTEM AUTEM/CRUCIS • MATEI 24

Pablo, Epistola a los filipenses, 2:8: "Humiliavit semet ipsum factus oboediens usque ad mortem, mortem autem crucis; propter quod et Deus illum exaltavit et donavit illi nomen super omne nomen". Mención a Mateo, 24. 
2) Evangelistas, en paño frontero:

ECCE LOCUS POSUERUNT

Marcos, 16:6: "Qui dicit illis: Nolite expavescere: Iesum quaeritis Nazarenum, crucifixum, surrexit, non est hic, ecce locus ubi posuerunt eum"

INTR... VIDI ET CR...

Juan, 20:8: "Tunc ergo introivit et ille discipulus qui venerat primus ad monumentum: et vidit et credidit".

3) Figuras femeninas, en los paños laterales, de izquierda a derecha:

POSUERUNT

Marcos, 6:29: "Quo audito, discipuli eius venerunt, et tulerunt corpus eius: et posuerunt illud in monumento".

Juan, 19:42: "Ibi ergo propter parasceven Iudaeorum, quia iuxta erat monumentum, posuerunt Iesum".

Juan, 20:13: "Dicunt ei illi: Mulier, quid ploras? Dicit eis: Quia tulerunt Dominum meum: et nescio ubi posuerunt eum".

VICIT LEO DE TRIBU

Apocalipsis, 5:5: "Et unus de senioribus dicit mihi: Ne fleveris: ecce vicit leo de tribu Iuda, radix David, aperire librum et solvere septem signacula eius".

SEBILLA CUMANA

ET ERIT SEPULCHRUM EIUS

Isaías 11:10: "In die illa radix Iesse, qui stat in signum populorum, ipsum gentes deprecabuntur, et erit sepulchrum eius gloriosum".

En los muros:

1) Tableros superiores, izquierdo y derecho:

EGO TORCULAR CALCABI [sic] /SOlus ET DE GENTIBUS

Isaías 63:3: "Torcular calcavi solus, et de gentibus non est vir mecum; calcavi eos in furore meo, et conculcavi eos in ira mea: et aspersus est sanguis eorum super vestimenta mea, et omnia indumenta mea inquinavi" ["Pisé las uvas yo solo, nadie me ayudó. Lleno de ira pisoteé a mis enemigos, los aplasté con furor y su sangre salpicó mis vestidos y manchó toda mi ropa"].

2) Tableros inferiores, muro izquierdo:

QUIS REVOLVET NOBIS LAPIDEM AB OSTIUM MONUMENTI

Marcos, 16:3: "Et cum transisset sabbatum, Maria Magdalene, et Maria Jacobi, et Salome emerunt aromata ut venientes ungerent Jesum. Et valde mane una 
sabbatorum, veniunt ad monumentum, orto jam sole. Et dicebant ad invicem: Quis revolvet nobis lapidem ab ostio monumenti?".

OCCURIT A[utem] IESUS ET ALI MULIERIB[us] DICENS AVETE ILLE AUT[em] ACCESERUNT ET TENUERUNT PEDES EIUS ET ADORAVERUNT EUM

Mateo, 26:9: "Et exierunt cito de monumento cum timore et gaudio magno, currentes nuntiare discipulis ejus. Et ecce Jesus occurrit illis, dicens: Avete. Illce autem accesserunt, et tenuerunt pedes ejus, et adoraverunt eum. Tunc ait illis Jesus: Nolite timere: ite, nuntiare fratribus meis ut eant in Galilæam; ibi me videbunt".

3) Tableros inferiores, muro derecho:

SURGENS IESUS MANE PRIMA SABBATI APARVIT PRIMO MARIAE MAGDALENAE STABAT AD MONUMENTUM FORIS PLORANS

Marcos, 16:9: Surgens autem mane prima sabbati, apparuit primo Marice Magdalene, de qua ejecerat septem dæmonia".

Juan, 20:11: "Maria autem stabat ad monumentum foris, plorans. Dum ergo fleret, inclinavit se, et prospexit in monumentum: et vidit duos angelos in albis sedentes, unum ad caput, et unum ad pedes, ubi positum fuerat corpus Jesu".

CONGRATULAMINI MIHI OMNES QUI DILIGITIS DOMINUM, QUIA QUEM QUAEREBAM APPARUIT MIHI: ET DUM FLEREM AD MONUMENTUM, VIDI DOMINUM MEUM

["Alegraos conmigo cuantos amais al Señor, porque aquel a quien buscaba se me apareció; y mientras lloraba junto al sepulcro, vi a mi Señor"].

Motete (Crecquillon; Palestrina; Guerrero, 1566; Victoria, 1572).

Esta común fórmula de júbilo aparece en los episodios de la oveja encontrada y el dracma encontrado, Lucas, 15:6 y 9: "Congratulamini mihi, quia inveni ovem meam, quæ perierat"; "Congratulamini mihi, quia inveni drachmam quam perdideram". 